Pamiętnik Literacki 2013, 1, s. 45-82
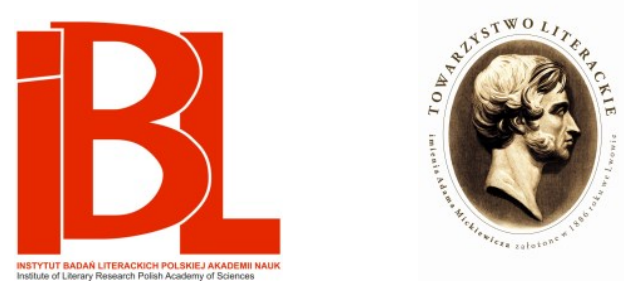

\title{
Opisać filmikowanie
}

„Eulalia” jako ekfraza filmiku „Napad na stacji”

Izabela Tomczyk 
Pamiętnik Literacki CIV, 2013, z. 1

PL ISSN 0031-0514

\title{
IZABELA TOMCZYK
}

(Uniwersytet Kardynała Stefana Wyszyńskiego, Warszawa)

\author{
OPISAĆ FILMIKOWANIE ${ }^{1}$ \\ „EULALIA” JAKO EKFRAZA FILMIKU „NAPAD NA STACJI”
}

Pierwotnie tytuł tekstu zamieszczonego przez Białoszewskiego w tomie Przepowiadanie sobie miał brzmieć Napad na stacji, jednak jeszcze w maszynopisie poeta zamienił go na Eulalia. Korekta niewielka, acz znacząca dla interpretacji. Napad na stacji to filmik, który realizowany jest w mieszkaniu Dudy oraz Mariana i którego projekt zostaje przez Mariana przedstawiony przybyłym aktorom. Tytuł utworu powtarzający tytuł filmiku koncentruje czytelniczą uwagę na tym, co dzieje się na „domowym planie” wokół kreowanej scenki, a dzieje się sporo. Po zwięzłej prezentacji kolejno pojawiających się osób, ich zachwytów nad nową uczestniczką filmikowania, czyli lalą Eulalią, po drobnych napięciach wynikłych z zazdrości (?) o urodę Eulalii, następuje krótkie zarysowanie akcji scenki, w jakiej aktorzy mają zagrać, dzielenie się opowieściami i refleksjami o duchach oraz kręcenie filmiku zakończone straszną awanturą.

Kiedy Marian przedstawia zarys swojego pomysłu na filmik, mówi:

Tak, tu akcja, ty masz tańczyć, jako Cyganka, oni czekają na stacyjce na pociąg, zagapiają się, ty się podkradasz w tańcu do kasy, oni pukają w okienko. Ty już ze środka udając kasjerkę: „Proszę, dokąd?”, sprzedajesz bilety. W końcu wypadasz z drzwi kasy czyli łazienki i rozzuchwalona zdobyczą z kasy napadasz na nich. Wyrywasz kobietom klejnoty. Uciekasz. [B 294 $]^{2}$

1 Filmikowanie to ciągle jeszcze mało znana forma działalności Mirona Białoszewskiego, jaką uprawiał on od mniej więcej 1965 r. do końca lat siedemdziesiątych. Po filmikowaniu pozostały nagrane na taśmę $8 \mathrm{~mm}$ krótkie scenki - filmiki. Scenariusz poszczególnych filmików Białoszewski wymyślał do spółki z Romanem Klewinem - przyjacielem, tłumaczem E. A. Poego, twórcą eksperymentalnego teatru. Autorką scenografii była Adriana Buraczewska - żona Klewina. Aktorami filmikowania byli: Ewa Berberyusz, Krzysztof Białek, Eryk Buraczewski, Malina Gamdzyk, Grażyna Jaworska, Gracja Kerényi, Julian Kiełkiewicz, Agnieszka Kostrzębska, Halina Oberländer, Elżbieta Piotrowska, Anna Sobolewska, Tadeusz Sobolewski, Jadwiga Stańczakowa, Anna Żurowska. Spotykano się w mieszkaniu Klewinów na warszawskim Żoliborzu. Mieszkanie artystów, pełne rzeźb i surrealistycznych obrazów Buraczewskiej, stanowiło doskonałą przestrzeń do realizacji filmików, których pomysł wywodził się z fascynacji kinem niemym i snem.

2 W ten sposób odsyłam do: M. B i ał o s z e w s k i, Eulalia. W: Przepowiadanie sobie. (Wybór próz). Warszawa 1981. Liczby po skrócie oznaczają stronice. We wszystkich cytatach z tekstów Białoszewskiego zachowuję specyficzną interpunkcję autora. 
Zaczyna się nakręcanie scenki. Marian, operując kamerą, jednocześnie reżyseruje postacie i, jak w kinie niemym, podrzuca im na głos sposób działania. Całość scenki otwiera niezwykle dynamiczny taniec Feluni. Reżyser-operator widząc, że wymyka się ona kamerze, prosi ją o złagodzenie ruchów, po czym zwraca się do reszty uczestników:

Tak, proszę pasażerów o chwilę spania i rozbudzenie się, ruch zbiorowy, reakcja na Cygankę, uwaga, kręcę, panie Ursynie, pan podziwia Cygankę... Cyganka ciaśniej. [B 296]

Podobnie jak na planie niemej komedii - oprócz instrukcji reżysera toczą się dodatkowo rozmowy. Jadźwinka wypomina Ursynowi brak zainteresowania jej osobą, Ciacia również jest rozgoryczona obojętnością Ursyna, czemu daje wyraz wyrzucając z siebie siarczyste „Psiakrew!” (B 296), Duda speszona koniecznością gry wychodzi poza przedstawioną sytuację filmikową i zaczyna opowiadać o swojej podróży do Paryża. Ani speszenie Dudy przykrywane własnymi doświadczeniami z życia, ani rozmowy toczone w tle realizacji scenki, czyli mieszanie rozmaitych porządków, nie psują efektu, filmik jest przecież niemy, głosu i tak nie słychać.

To, co daje się dostrzec w tym fragmencie prozy, to różnice zachodzące pomiędzy opowiadanymi historyjkami. Wersja zreferowana przez Mariana zupełnie nie przystaje do tego, co zostało zrealizowane. Różnica zauważalna jest w porządku diegetycznym (słowom Mariana przeciwstawiono relację narratora trzecioosobowego), ale jest to również różnica związana z formą wypowiedzi. Tekst, słowo wyrażone przez Mariana nie przekłada się na działanie. Kody tych dwóch form wypowiedzi nie pasują do siebie, nie są tożsame.

Do dwóch napadów na stację dołożyć można jeszcze jeden. Kiedy wyłącza się kamera, korytarz-stacja (plan filmikowania) staje się miejscem awantury i napaści na lalę Eulalię. Działające tu postacie nie są już aktorami-bohaterami filmiku, są aktorami-przyjaciółmi, którzy przyszli do Dudy i Mariana. Ich emocje nie wynikają z poddanego im scenariusza, ale stanowią konsekwencję określonej sytuacji. Akcji nie zarysował uprzednio żaden $\mathrm{z}$ bohaterów, nie ma nadrzędnego reżysera, intradiegetycznego stylisty. Sytuacja motywowana i napędzana jest emocjami, które przez cały utwór budowane są w specyficzny sposób. Od punktu zerowego, w jakim rozpoczyna się opowiadanie: „Eulalia siedziała bez najmniejszego ruchu” (B 291), poprzez drobne fluktuacje do granicy stagnacji:

I wszyscy troje trwali w zastygłości przez dwadzieścia minut.

Z prawej strony słychać było zza drzwi krzątaninę aparatową Mariana, z lewej z daleka delikatne pobrzękiwanie stosów Dudy. W łazience kapała woda. [B 293]

Po czym następuje dzwonek do drzwi i - w momencie pojawienia się kolejnych gości - gwałtowne wybicie emocjonalnej krzywej w górę. W powstających między bohaterami relacjach emocje co chwila ocierają się o granice możliwości panowania nad nimi, dobijają do punktu, w którym uniknięcie nieprzyjemnej sceny lub wręcz awantury wydaje się niewykonalne:

Ach, co to za nowa piękność, mów o sobie [na wejściu mówi do Eulalii Ciacia - I. T.]...

Felunia się skrzywiła. [B 293-294]

Albo inny fragment: 
Pani Jadźwinka:

- Czy Eulalia ma klejnoty?

- A jakże, zausznice i medale z migotem. [B 294]

\section{Dalej:}

Jadźwinka naburmuszona, trochę znudzona. Cyganka Felunia na próżno zagląda w ukłonach tanecznych panu Ursynowi w oczy i w okulary, tak mu się przecież zawsze podobała. A dziś? On widzi tylko Eulalię. Nie pomogło szczypanie go w łokieć przez Ciacię.

- Psiakrew! [B 296]

Po czym emocje zostają rozładowane nieprzewidzianym gestem, wtargnięciem osoby trzeciej czy instrukcją reżysera dotyczącą sposobu gry. Jednak ta piętrząca się sinusoida emocjonalna musiała w końcu osiągnąć punkt krytyczny. Kobiety zaatakowały Eulalię. Narrator podsyca dramatyzm sytuacji, w jakiej znalazła się lala, informując, że zajęci innym działaniem zarówno Marian, jak i Duda nie mogą jej pomóc. Jedynym, którego na to stać, jest pan Ursyn. To on spostrzega osaczenie Eulalii, rzuca się jej na ratunek, ujmując w ramiona i unosząc do drugiego pokoju. Całość scenki, która rozgrywa się na poziomie diegezy, opowiedziana przez trzecioosobowego narratora, nieodparcie przypomina burleskowe komedie Charliego Chaplina, którą komik realizował w wytwórni Senetta. Tam kilkanaście minut musiało wystarczyć, by doprowadzić akcję do pogoni lub bitwy na torty. Tu kilkanaście minut prowadzi do równie widowiskowego wybuchu emocji. Scenka umiejscawia przestrzeń planu filmowego w kadrze, nakłada na niego filtr, który odsyła ponownie w przestrzeń filmiku.

Pierwotny tytuł utworu, będący przytoczeniem tytułu (potrojonego) filmiku, zdradza grę z czytelnikiem prowadzoną przez Białoszewskiego. Ma się wrażenie, że poeta żongluje wieloznacznością sytuacji, zwielokrotnionym odbiciem lustrzanym (dodajmy, że jest to krzywe lustro) rzeczywistości na planie i sytuacji z filmiku. Zmusza do szukania sensu rodzących się relacji. Jednak taka sytuacja Białoszewskiemu jakby nie wystarcza.

Kim albo raczej czym jest tytułowa Eulalia? Z treści opowiadania dowiadujemy się, że jest to lala, rzeźba wykonana z masy papierowej. „Bardzo dobra, chociaż twarda" - mówi Jadźwinka, po tym jak zbadała lalę palcami. Dalej czytamy:

Duda opuściła story w kuchni i tłumaczyła się:

- Dużo było z nią trudu, naklejanie warstwy na warstwę. [B 292]

Z drugiej strony, lala jest tak piękna, że łudząco przypomina kobietę. Prowadzi to do katastrofy, bo zauroczenie pana Ursyna urodą nowej uczestniczki zajęć kamerowych wzbudza zazdrość przybyłych pań.

Podobnie jak trudno było uchwycić właściwy „napad na stacji”, tak w przypadku Eulalii czytelnik do końca nie ma pewności, czy Eulalia to lalka, czy kobieta. Wybór imienia bohaterki na tytuł utworu powoduje, że czyni ją to centralną postacią, i transformacja dokonana w ramach tej osoby wydaje się ważniejsza dla Białoszewskiego niż rozstrzygnięcie kwestii dotyczącej Napadu na stacji ${ }^{3}$.

3 Znamienne jest to, że wszystkie imiona bohaterów zmieniono, dźwiękowo zdeformowano (Adriana Buraczewska została Dudą, Roman Klewin - Marianem, Jadwiga Stańczakowa - Jadźwinką, Julian Kiełkiewicz - Ursynem, Anna Żurowska - Felunią, a Halina Oberländer, czyli Kicia Kocia - Ciacią), tylko imię Eulalii pozostało takie samo. 
Niebywale ważne jest również imię, które - wykorzystane w funkcji tytułu wymusza, by osoba analizująca tekst sięgnęła po jego znaczenie. Władysław Kupiszewski w przygotowanym przez siebie słowniku imion tak thumaczy to imię:

Eulaliusz m., Eulalia ż., z gr. eu - 'dobrze' i 'lalia' - mowa, czyli ‘mający walory mówcy'; łac. Eulalius m., Eulalia ż., hiszp. Eulalis m., Eulalia ż., ukr. Jewlalija ż., serb.-chorw. Eulalija, Ela, Lala ż. ${ }^{4}$

Przeprowadzony przez Kupiszewskiego rozbiór znaczeniowy pozwala zbudować dwa główne konteksty. Serbsko-chorwacka wersja zdrobnienia imienia Eulalia w polskim uchu zdaje się w jakiejś części tłumaczyć oscylowanie tej postaci między kobietą a lalą, pozwala domniemywać, że oscylacja jest zakodowana już w samej nazwie (inne konsekwencje braku dookreślenia staną się przedmiotem dalszej analizy tekstu). Imię, nazwa oznaczająca kobietę/osobę, która dobrze mówi, definiujące osobę z darem wymowy zdaje się wskazywać trop, jakim należy podążyć w próbie odczytania tekstu. Mówca, wprawnie posługujący się słowem, wypowiadający się o sztuce (o filmiku Napad na stacji) - to retor, który buduje ekfrazę. Eulalia jest o tyle znacząca w powiązaniu z ekfrazą, ze zjawiskiem ekfrastycznym, że to jedyny tekst w twórczości Białoszewskiego, który poeta w całości poświęcił filmikowaniu 5 .

W Eulalii odsyła się do dwóch scenek z filmików zarejestrowanych w mieszkaniu Klewinów na Żoliborzu. Pierwsza z nich nosi rzeczywiście tytuł Napad na stacji, z drugiej Białoszewski zaczerpnął pewne elementy, konstruując świat przedstawiony narracji.

Napad na stacji zarejestrowany w czasie filmikowania rozgrywa się na korytarzu mieszkania Klewinów, który ma być poczekalnią ${ }^{6}$. Na ławce pod ścianą siedzi Eryk Buraczewski - ojciec Ady Buraczewskiej, i Kicia Kocia. On trzyma w ręku mały elektryczny odkurzacz, ona czyta książkę i pali papierosa. Naprzeciwko nich na podłodze leży pies Boy. Pojawia się Białoszewski w peruce. Lekko skulony patrzy na rozkład jazdy rozwieszony na ścianie nad ławką. Za wszelką cenę chce również sprawdzić, która jest godzina, natarczywie ogląda zegarek, jaki postać grana przez Kicię Kocię ma na ręku. Sprawdzanie godziny i rozkładu powtarza się kilkakrotnie. W końcu bohater Białoszewskiego siada na ławce. Wpada Barbara Zbrożyna z atrapami pistoletów w dłoniach. Straszy pasażerów, szarpie ich. Po czym silnie pociąga Kicię Kocię za ubranie. Kobiety zaczynają się szamotać na podłodze. Kicia Kocia podnosi się z podłogi, siada na ławce. Zbrożyna bawi się z psem. Kicia Kocia wstaje i wychodzi. Białoszewski podsuwa się do Buraczewskiego, zaczynają oglądać odkurzacz.

Wśród zarejestrowanych scenek ze Snu pięciu osób jest również filmik skła-

4 W. K u p i s ze w s k i, Dlaczego Agnieszka, a nie Ines? Wybierz imię dla swojego dziecka. Warszawa 1991, s. 73-74.

5 Nie tylko w Eulalii mowa jest o filmikowaniu, Białoszewski wspomina o tym również w Majowym przejściu, Bielanach i w Siostrze Eulalii.

6 Chcąc zbadać Eulalię jako ekfrazę czy zjawisko ekfrastyczne filmików, zmuszona jestem wskazać na charakterystyczne elementy, które konstruowały wspomniane przeze mnie filmiki, czyli mówiąc o ekfrazie, sama posługuję się pewnymi elementami stanowiącymi o ekfrazie. Jednak ze względu na to, że żoliborskie filmiki nie są szeroko dostępne, trzeba, aby taki zapis znalazł się w tym fragmencie. 
dający się z trzech epizodów. Pierwszy przedstawia salon pani Żeni, w którym kobiety poddają się zabiegom pielęgnacyjnym, grają i wróżą z kart. Obok salonu postać odtwarzana przez Juliana Kiełkiewicza prowadzi warsztacik naprawczy ${ }^{7}$. Kiełkiewicz siedzi przy niedużym okrągłym taborecie, na którym leży szczotka do obuwia, pudełko, obcęgi. Trzyma w ręku budzik, próbuje go naprawiać. Kamera prowadzona jest tak, by pokazać twarz Kiełkiewicza, a za chwilę jego mały warsztacik. W tle za Kiełkiewiczem widoczna Eulalia, próba poprowadzonego z dołu zbliżenia na twarz lali ${ }^{8}$. Za chwilę na pierwszym planie nieostro dostrzegalna jest Żenia (Kicia Kocia) z grzebieniem w ręku. Czesze klientki. Żenia podchodzi do taboretu-warsztaciku i przekłada na nim przedmioty. Postać odgrywana przez Kiełkiewicza zaczyna się buntować. Broniąc się przed tą interwencją uderza delikatnie w dłoń kobiety. Ona odpowiada mu również gwałtowniejszym ruchem dłoni. Przebitka z Kicią Kocią siedzącą na fotelu. Kolejny epizod, dalej zbudowany wokół gry rękoma. Eulalia w kwiecistej sukni, przykryta szerokim szalem, który zasłania stającą za lalą kobietę ${ }^{9}$. Spod szala wystają tylko ręce. Nieruchoma lala gra rękami kobiety. Kobieta-lalka uwodzi mężczyznę siedzącego za warsztacikiem. Kiwa palcem na niego, splata dłonie, gładzi swoją (czyli lali) twarz. Mężczyzna wyciąga do niej rękę, całuje ją w dłoń. Kobieta-lalka głaszcze w powietrzu dłoń mężczyzny, zaczepia go. On odwzajemnia jej gest. Przez chwilę gra jest dość dynamiczna. Mężczyzna wstaje, odsuwa warsztacik, podchodzi do kobiety-lali. Obejmuje ją. Ta się broni, ruszając gwałtownie rękami. Mężczyzna podnosi ją i wychodzi z nią z pokoju. Ona ciągle macha rękami.

W prozie Białoszewski opisał filmik, który skonstruował z obrazów dwóch filmików realizowanych w realnej przestrzeni mieszkania na Żoliborzu. W filmiku odtworzonym w Eulalii połączył: scenkę zagraną przez Zbrożynę, scenkę z szamoczącymi się kobietami i psem Boyem, oraz dodał postać lali animowanej przez kobietę w taki sposób, że zlewają się one w jedną strukturę. Podobne jest również zachowanie postaci, w którą wcielił się Kiełkiewicz. Lala-kobieta, niesiona przez Kiełkiewicza i nieustająco grająca rękami, wydaje się obrazowym źródłem scenki zamykającej narrację, w której na odsiecz osaczonej Eulalii rusza Ursyn. Bierze ją w ramiona i wynosi do drugiego, ciemnego pokoju. Planu nie opuszczają kobiety. Ciacia patrząc na oddalające się sylwetki krzyczy: „Ona rusza rękami!! [...] rusza rękami!!"' (B 298).

Pozostałe dwie też nie potrafią dać sobie rady z emocjami:

- Aach - kucnęła Felunia z pięścią w ustach.

Pani Jadźwinka w wypiekach stała i wyciągała ręce. [B 298]

Sądzę, że nim przejdziemy do problemu ekfrazy, należy ponadto zauważyć

7 J. S tań c zak ow a w Dzienniku we dwoje (Warszawa 1992) opisuje bardzo podobną scenkę, co znacznie ułatwia odtworzenie pierwotnego pomysłu, wymienia jednak inne osoby niż te, które pojawiają się w odzyskanym filmiku. Można przypuszczać, że pomysł realizowano kilkakrotnie.

8 Omówienie filmików nastręcza pewną trudność, ponieważ większość zapisanego obrazu wydaje się efektem bardziej prób czy eksperymentów technicznych i chęci utrwalenia niż przemyślanego operatorskiego działania.

9 Z relacji Stańczakowej wynika, że w podobnym filmiku lalę animowała Anna Sobolewska, na oglądanym filmiku animatorką była najpewniej Kicia Kocia. 
jedną istotną rzecz. Słowo w kinie niemym istnieje na szczególnych zasadach, w filmikach jest ono jeszcze głębiej ukryte, bo filmiki - zgodnie z założeniami Białoszewskiego - to obrazy w ruchu, obrazy przedstawione w rytmie. Słowo (czy to w postaci komentarza uczestników, wewnątrzujęciowego napisu, czy w reżyserskiej podpowiedzi) pełni funkcję służebną w stosunku do obrazu, podobnie jak napisy na renesansowych obrazach Fra Bartolomea, które malarz umieszcza na wstęgach, księgach czy zwojach papieru. Spłycając problem - ekfraza jest przełożeniem znaku, jakim posługują się sztuki plastyczne, na słowo. Nie można mówić o ekfrazie filmu czy teatru, bo słowo stanowi ich nieodłączny element. Ze względu na poczynione przez Białoszewskiego spostrzeżenia dotyczące niemego kina filmiki umykają tym zastrzeżeniom, nie posługują się słowem w bezpośredni sposób. Filmiki są obrazem, tyle że obrazem w ruchu, dlatego wolno nam mówić o ich ekfrazie.

Trudno rozstrzygnąć, czy Białoszewski widział te filmiki, czy zapamiętał pewne obrazy, gdy je realizował. Tradycja retoryczna zna przypadki (o czym dalej w tekście) tworzenia ekfrazy dla obrazów nieistniejących, niemniej ważny w tym momencie wydaje mi się tekst Paula Ricoeura Proces metaforyczny jako poznanie, wyobrażenie i odczuwanie ${ }^{10}$ konstruującego schemat zależności między tym, co werbalne, a tym, co niewerbalne. Schemat, który w dużej mierze można przełożyć na funkcjonowanie ekfrazy czy zjawiska ekfrastycznego dzieł nie mających swojego materialnego ukonkretnienia.

Badacz, budując związek pomiędzy poznaniem, wyobrażeniem a odczuciem, z jednej strony zauważa:

Wyobraźnia i uczucie były zawsze ściśle powiązane w klasycznych teoriach metafory. Pamiętajmy, że retorykę nieodmiennie określano jako strategię wypowiedzi mającą za cel przekonywać i sprawiać zadowolenie. Znamy też kluczową rolę, jaką zadowolenie gra w estetyce Kanta ${ }^{11}$.

Z drugiej strony, rozpatrując aspekt wyobraźni, poszukuje jej semantycznej roli poprzez odniesienia do Arystotelesa. Czynnikiem, który powoduje, że wypowiedź jawi się w określony sposób, jest dykcja, elokucja i styl. Ricoeur tworzy w ten sposób swoistą zależność między obrazem a słowem. Dowodzi za Arystotelesem:

Twierdzi on też, że dar tworzenia udanych metafor polega na zdolności do dostrzegania podobieństw. Co więcej, plastyczność takich udanych metafor zależy od ich zdolności „stawiania przed oczami" sensu 〈sense , który sobą wyrażają. Nasuwa to myśl o wymiarze obrazowym, który można nazwać funkcją obrazow ą znaczenia metaforycznego ${ }^{12}$.

Dalej Ricoeur podpiera się tradycją retoryczną i przywołuje termin „figura retoryczna", który wskazuje, że zarówno w metaforze, jak i w innych tropach lub zwrotach wypowiedź ma w sobie niejako zakodowany potencjał cielesności. Objawia ona możliwość „,cielesnej eksternalizacji” " ${ }^{13}$. Przekaz, będąc w pewien sposób figuratywny, dzięki zastosowaniu tropów staje się jednocześnie widoczny.

Semantyczną rolę wyobraźni, czynnika obrazowego czy ikonicznego, upatru-

${ }^{10} \mathrm{P}$. R i c o e u r, Proces metaforyczny jako poznanie, wyobrazenie i odczuwanie. Przeł.

G. Ce nd row s k a. Przejrz. T. D o br z y ń s k a. „Pamiętnik Literacki” 1984, z. 2.

11 Ibidem, s. 282.

12 Ibidem, s. 270.

13 Ibidem. 
je Ricoeur w funkcji podobieństwa. Tworzenie udanych metafor polega na dostrzeganiu podobieństwa między pojęciami, terminami, w tym sensie wypowiedź, która jest niespójna z punktu widzenia dosłownej interpretacji wypowiedzi, nabiera znaczenia w interpretacji nowej. Dostrzeżenie owego podobieństwa rodzi napięcie. Powstająca stosowność wynika ze swoistej bliskości semantycznej, jaka tworzy się między terminami, które do tej chwili wydawały się od siebie odległe. Wyobraźnia jest w tym momencie miejscem gry odległości z bliskością, miejscem gdzie „pokrewieństwo rodzajowe nie osiąga pojęciowego spokoju i spoczynku” ${ }^{14}$. Dalej badacz objaśnia:

Zagadkę przedstawienia ikonicznego stanowi sposób, w jaki obraz ukazuje się w upodobnieniu predykatywnym: pojawia się coś, z czego odczytujemy nowy związek. Zagadka pozostaje nie rozwiązana tak długo, jak długo traktujemy obraz jako wizerunek w umyśle, tj. replikę rzeczy nieobecnej. Obraz musi wówczas pozostać obcy owemu procesowi, zewnętrzny wobec upodobnienia predykatywnego.

Musimy zrozumieć proces, w którego wyniku wytwarzanie obrazów ukierunkowuje schematyzację upodobnienia predykatywnego. Ukazując strumień obrazów, wypowiedź inicjuje zmiany odległości logicznych, generuje zbliżenia. Obrazowanie bądź wyobrażenie stanowi więc konkretny środek $\langle$ milieu $\rangle$, w którym i przez który widzimy podobieństwa ${ }^{15}$.

Ricoeur za Immanuelem Kantem i Paulem Henle zauważa jednocześnie, że element ikoniczy, obrazowy, jaki pojawia się w metaforze, nie jest tożsamy z przedstawieniem, ale $\mathrm{z}$ opisaniem. Wyobrażenie nie oznacza konstruowania w umyśle (imaginacji) wizerunku, to raczej kwestia tworzenia w sposób obrazowy związków. Nieważne, do czego odnosi się obrazowanie, czy dotyczy ono próby kreowania podobieństw, jakości, struktur, postaw, miejsc itd. - „za każdym razem ów nowy, zamierzony związek postrzegany jest jako to, co ikon opisuje bądź obrazuje". Badacz dodaje:

Mam wrażenie, że w ten sposób w obrębie semantycznej teorii metafory można oddać sprawiedliwość Wittgensteinowskiemu pojęciu „widzenia jako" ${ }^{16}$.

Doświadczanie obrazu, spojrzenie, w sytuacji, w której Białoszewski nie widziałby opisanych wcześniej przeze mnie filmików, nie jest formą opowiadania, stanowi akt percepcji, który pozwala opowiadać tak, a nie inaczej.

Czym jest ekfraza? Temu zagadnieniu twórcy Słownika terminów literackich nie poświęcają zbyt dużo uwagi. Janusz Sławiński tak tłumaczy to określenie:

Ekfraza (< gr. ékphrasis = dokładny opis) - utwór poetycki będący opisem dzieła malarskiego, rzeźby lub budowli, np. Oda do urny greckiej J. Keatsa ${ }^{17}$.

The Oxford Classical Dictionary rozszerza zasięg semantyczny pojęcia i do-

${ }^{14}$ Ibidem, s. 275.

15 Ibidem, s. 276.

${ }^{16}$ Ibidem, s. 277

17 Ekfraza. Hasło w: M. Głowiński, T. Kostkiewi c zowa, A. Okopień-Sław ińs k a, J. Sła w iń s k i, Słownik terminów literackich. Wyd. 3, poszerz. i popr. Wrocław 2000, s. 122. 
datkowo je komplikuje. Przytoczona tam definicja nie ogranicza terminu tylko do utworów poetyckich, nie zamyka go również w obrębie dzieł sztuki, ponadto wskazuje, że ekfraza może dotyczyć tak przedmiotu realnego, jak i przedmiotu wyimaginowanego ${ }^{18}$. Obie definicje są pobieżne, wymieniają jedynie pewne cechy ekfrazy, co więcej, w jakimś stopniu się nawet wykluczają. Trudno sądzić, że taka sytuacja stanowi tylko przypadek, musimy poszukać przyczyn, by przybliżyć granice ekfrazy, co z kolei umożliwi właściwe ustawienie - wobec zarysowanego znaczenia terminu - utworu Białoszewskiego Eulalia oraz pozwoli na rozważenie w tym kontekście relacji pomiędzy słowem, opowieścią o sztuce, opowieścią o obrazie a obrazem.

Gdy przyjrzeć się nieco bliżej zagadnieniu, staje się jasne, że w zasadzie od samego początku pojęcie to nastręczało sporo problemów, głównie ze względu na fakt, iż na przestrzeni historii dość dynamicznie zmieniało swój zakres znaczenia. Michał Paweł Markowski, notując - przy okazji tworzenia wybiórczej, acz reprezentatywnej, bibliografii przedmiotu - krótką historię terminu, rozpoczyna od wskazania znaczenia słowa na gruncie klasycznej retoryki. Retorycy pojmowali ekfrazę - tu Markowski powołuje się na autorytet Kwintyliana - jako figurę, ozdobnik mowy, którego zadaniem było przedstawienie rzeczy, jakie się rozpatruje, na tyle jasno i wyraźnie, by unaoczniały się one słuchaczom, ,żeby zdawało się, że mamy je przed oczami [...]" ${ }^{19}$. Znaczenie to rozsypuje się dodatkowo na kilka wymiennie używanych pojęć. Obok ekfrazy w tekście Markowskiego pojawiają się: diatyposis, hypotyposis, enargeia. Ponadto terminy greckie mieszały się z określeniami łacińskimi: evidentia, descriptio, demonstratio. Również Heinrich Lausberg przywołany przez Markowskiego dodaje, że ekphrasis albo descriptio traktowane były także jako specyficzne ćwiczenia dla młodych adeptów retoryki zmierzające do enargei: „,bezpośrednia prezentacja rzeczy przed oczami adresata” ${ }^{20}$. Owa bezpośrednia prezentacja, dokonana za pomocą opisu, z jednej strony dotyczyła rzeczy, z drugiej - postaci (czyli charakter lub portret - jak doprecyzowuje Markowski). Z opisu rzeczy wydzielono jeszcze ekphrasis na oznaczenie omówień dzieł sztuki (zarówno obrazów, jak i rzeźb czy budowli). Konsekwencją całego tego procesu - jest, zdaniem badacza, następujący fakt:

dziś używa się terminu ,ekphrasis” w węższym (opis dzieła sztuki) i szerszym (opis jako taki) znaczeniu. W węższym znaczeniu możemy mówić zarówno o opisach dzieła sztuki w utworze literackim (Homer), jak o osobnym gatunku, zapoczątkowanym przez Eikones (Obrazy) Filostrata Starszego, z przełomu II i III w. po Chrystusie. W szerszym zaś - o strategii opisu w utworze narracyjnym (o czym pisał Kwintylian ${ }^{21}$.

Według autora ekfraza zbudowana jest na stałym napięciu między iluzyjną wiarą w przezroczystość znaków językowych a świadomością ich nieprzezroczystości, która w ogóle warunkuje pisanie. Jest ona, zdaniem Markowskiego, kluczo-

18 S. Hornblower, A. Spaw forth, The Oxford Classical Dictionary. Ed. 3, revised. Oxford - New York 2000.

${ }_{19}$ M. P. M a r k o w s k i, Ekphrasis. Uwagi bibliograficzne z dołaczeniem krótkiego komentarza. „Pamiętnik Literacki” 1999, z. 2, s. 229.

${ }^{20}$ Ibidem.

${ }^{21}$ Ibidem. W kontekście definicji Sławińskiego i tej przytoczonej przez The Oxford Classical Dictionary oraz w kontekście przede wszystkim interesującego mnie w tym momencie tekstu Białoszewskiego Eulalia warto zauważyć, że Obrazy Filostrata Starszego pisane są prozą. 
wą kategorią dla prowadzenia badań nad „obrazującymi, opisowymi, czyli najogólniej: wizualizującymi możliwościami języka, lub - ujmując rzecz inaczej - nad szansą uobecnienia w dyskursie tego, co pozajęzykowe" 22 .

Adam Dziadek, doprecyzowując pojęcie uobecnienia w kontekście ekfrazy, sięga do opracowań i omówień Retoryki Arystotelesa dokonanych przez Longina, Cycerona i Kwintyliana ${ }^{23}$. Dla wymienionych uobecnienie, unaocznienie faktów (evidentia) oznaczało wywołanie w słuchaczu żywych emocji. Drugi istotny problem dla ekfrazy, czyli opis i opisowość, tłumaczy Dziadek za Hermogenesem, dla którego pojęcie to określa wypowiedź, sprawiającą, że rzeczy są nam przedstawione szczegółowo i niemal zmysłowo przez nas widzialne. Pociąga to za sobą zasadniczą konsekwencję. Otóż słuchacz staje się widzem ${ }^{24}$.

Problem ekfrazy i wyimaginowanego przedmiotu podsunięty nam przez autorów The Oxford Classical Dictionary rozważa dosyć szczegółowo Johannes Th. Kakridis w eseju Imagined Ecphrases ${ }^{25}$. Zagadnienie ekfrazy imaginacyjnej thumaczy filolog na przykładzie niebywale często podawanego, jako typowa realizacja tej formy wypowiedzi, opisu z Iliady Homera: tarczy Achillesa. Kakridis zauważa, że tylko w jednym punkcie opis ten jest zgodny z wyglądem tarcz, jakie znać mógł Homer. Otóż tarcze z VIII w. p.n.e. były okrągłe, kilkuwarstwowe i zdobione koncentrycznymi okręgami. Reszta opisu służy Homerowi do przedstawienia idei porządku kosmicznego i ludzkiego ${ }^{26}$.

Greckie korzenie tego gatunku sięgają przede wszystkim spuścizny Filostrata Starszego, którego uznaje się za autora najważniejszego zbioru omówień dzieł sztuki. Jego Obrazy pisane były z przeznaczeniem do ćwiczeń retorycznych. Ukazane w postaci pogadanek - jak nazywa Filostrat swoje utwory - przykłady malarstwa miały służyć nauce interpretacji obrazów i ocenie tego, co jest w nich uważane za wartościowe. Od samego więc początku ekfraza wiązała się ze świadomym wyborem z dzieła (obrazu, rzeźby, budowli) tego, co dla artysty (opowiadacza) stanowi esencję ukazywanego dzieła.

Stworzone przez Filostrata ekfrazy to nie opisy dla samego opisu, są one tak pomyślane, by ich treść wyrabiała smak estetyczny. Obrazy nie zadowalają się wyłącznie mimetyzmem. Zbiór traktować należy jako interpretację malowideł znajdujących się na ścianach galerii, której właścicielem był neapolitański przyjaciel autora. Co więcej, stworzone przez Filostrata przedstawienia tak dalece odbiegają od obrazów rzeczywistych, że wielu badaczy przyjmowało, iż są to owoce wyobraźni. Późniejsze badania pokazują jednak, że analiza Filostrata dotyczyć może prawdziwych malowideł. Jan Białostocki komentuje:

Relacja o micie lub historii przeplata się więc u Filostrata z relacją o artystycznym wyobrażeniu i nieraz zyskuje nad nią przewagę, z czego wynikają wątpliwości co do charakteru jego dzieła ${ }^{27}$.

${ }^{22}$ M arkowski, op. cit., s. 229.

23 A. D z i a d e k, Obrazy i wiersze. Z zagadnień interferencjacji sztuk w polskiej poezji wspótczesnej. Katowice 2004, s. 51.

${ }^{24}$ Zob. ibidem.

${ }^{25}$ J. Th. K a k r i d i s, Imagined Ecphrases. W: Homer Revisited. Lund 1971.

${ }_{26}$ Zob. ibidem, s. 108-124.

${ }^{27}$ Myśliciele, kronikarze i artyści o sztuce. Od starożytności do 1500. Wybór, oprac. J. B i ał o s t o c k i. Wyd. 2, popr. i uzup. Warszawa 1988, s. 131. 
Homer - co również zauważa historyk sztuki - idzie jeszcze dalej. W poematach odnaleźć bowiem da się kilka opisów fikcyjnych dzieł sztuki, które zalicza się do najstarszych omówień tego typu. Autor Iliady i Odysei koncentruje się przede wszystkim na temacie, udział twórcy jest przez Homera określany poprzez przymiotniki pozytywnie wartościujące mistrzostwo imitowania rzeczywistości. Na podstawie opisów Homera trudno oddzielić możliwości, jakimi dysponowało rzemiosło artystyczne w epoce współczesnej autorowi, od tego, co podsunęła mu wyobraźnia ${ }^{28}$.

Wszystkie wymienione dotąd przykłady ujęcia problemu bardziej pokazują złożoność zagadnienia i jego historii, niż doprecyzowują je na tyle, by - pochylając się nad konkretnymi dziełami - bez wahania wskazać palcem to, które zechcemy nazwać ekfrazą i które tak zdefiniowane zacznie pracować w procesie interpretacyjnym. Aby tę pewność mieć, należy zadać pytanie o kwantyfikatory, cechy charakterystyczne ekfrazy, które pozwolą odseparować ją od innych utworów.

Dziadek, stawiając konieczne pytanie, buduje siatkę wyznaczników tej formy wypowiedzi dla literatury współczesnej ${ }^{29}$. Jego zdaniem, dany tekst literacki (liryka, fragment prozy, dramatu) może zostać uznany za ekfrazę, jeżeli ma w swej strukturze wyrażenia metajęzykowe, oznaki odsyłające bezpośrednio do konkretnego dzieła malarskiego, rzeźbiarskiego lub architektonicznego. Przy czym, podobnie jak Kakridis, Dziadek zwraca uwagę na fakt, że ekfraza dotyczy czasem jakiegoś nieistniejącego dzieła sztuki. Odsyłacze funkcjonują na różnych poziomach struktury tekstu. Metajęzykowe znaki są w stanie ujawnić się w powtórzonym tytule dzieła, o którym mowa, jego podtytule, autorzy często wymieniają nazwisko twórcy. Sam termin „ekfraza” może przejąć rolę tytułu lub podtytułu, definiując (niekiedy jednak pozornie, na zasadzie gry z czytelnikiem) przynależność utworu.

Kolejny wyznacznik to elementy opisu dzieła opowiadanego przez utwór, pozwalające czytelnikowi wskazać określony desygnat. Przedstawienie może dotyczyć techniki malarskiej, klasyfikować gatunek malarski, dotykać motywów charakterystycznych dla malarza (rzeźbiarza) wybranego przez autora ekfrazy. Klasycy, dokonując omówienia artystycznego, eksponowali interesujące ich elementy, twórcy współcześni jeszcze bardziej radykalizują ten wybór, ograniczając się często do kilku jedynie znaków wskazujących na konkretne dzieło. Selekcja tak samego dzieła, jak i elementów tego dzieła nie jest kwestią czystego mimetyzmu czy tylko samego opisu. Ten ostatni staje się podstawą do stworzenia autonomicznego dzieła literackiego, tekst wyjściowy poddany jest interpretacji i lekturze. Znamienne, że swoisty nadmiar w wyszukiwaniu semantycznych pól, konotacji, interpretacji rozbudowany jest w literaturze współczesnej kosztem dokładności opisu, ograniczonego do kilku kresek. Zdaniem Dziadka:

Ekfraza literacka wykracza zwykle poza samo dzieło sztuki, nie sprowadza się do imitowania barw, kresek czy kształtów zawartych w danym dziele za pomocą środków językowych, ale raczej reprezentuje dane dzieło - i z tego właśnie wynika jej nazwa ${ }^{30}$.

Problem z ekfrazą w literaturze najnowszej to przede wszystkim problem

\author{
28 Zob. ibidem, s. 114. \\ ${ }^{29} \mathrm{D}$ zi i d e k, op. cit. \\ ${ }^{30}$ Ibidem, s. 72. Obok „ekfrazy literackiej” Dziadek wydziela „ekfrazę krytyczną”.
}


rozbijania ustalonych norm. Wśród współczesnych tekstów - jak referuje Dziadek - trudno znaleźć takie, które bez obaw można by zaklasyfikować jako ekfrazy spełniające klasyczne kryteria. Zdaniem badacza, literaturze najnowszej, gdy dbać o precyzyjność w użyciu klasycznych terminów, bliższe w tym zakresie jest posługiwanie się określeniami: „zjawisko ekfrastyczności”, ,charakter ekfrastyczny dzieła", niż ekfrazą jako taką. Co więcej, współczesne teksty atakują statyczną, klasyczną ekfrazę. Michael Davidson, analizując wiersze Franka O'Hary i Johna Ashberego, tłumaczy tę sytuację odmienną świadomością twórców współczesnych w stosunku do klasycznych ${ }^{31}$. Najnowsza poezja nie przypisuje sobie zdolności mimetycznych, nie przejmuje na siebie jakości, którymi posługuje się malarstwo. Dla niej główny wyraz stanowi środek przekazu. Poezja jest (chce być) samoświadoma, dlatego ,przekręca powierzchnię lustra w swoją stronę, a nie na zewnątrz, tak jak to miało miejsce niegdyś" ${ }^{2}$. Formuła „ut pictura poesis" została podważona przez Gottholda Ephraima Lessinga, jednak z drugiej strony - jak zauważa Davidson - ten sam Lessing daje narzędzia do szukania innych płaszczyzn ,porozumienia sztuk", już nie rozgrywających się w warstwie mimetycznej:

To właśnie Lessing był tym, który kategorie przestrzennych i czasowych form zastosował do malarstwa i poezji, dzięki czemu ich środki przekazu miały odróżnić się od siebie. To również Lessing stworzył niektóre z „,podstawowych” metafor; późniejsi interpretatorzy sformułowali, wzorując się na nich, teorię moderny. Joseph Frank, by posłużyć się oczywistym przykładem, przejmuje ideę przestrzennej formy i stosuje ją do współczesnej powieści i poezji. W dziełach Flauberta, Pounda i innych zawarta jest tendencja do przedstawiania symultanicznej perspektywy danego momentu przez posłużenie się ujednoliconymi mediacjami (unifying connectives), tj. obiektywnym korelatem, ideogramem, „metodą mityczną” (poprzez dążenie do zniszczenia jakiegokolwiek poczucia chronologicznych następstw czasowych lub naturalistycznej perspektywy). Pisarze ci - utrzymuje Frank - ,perfekcyjnie nakłaniają czytelnika, aby ujmował ich dzieło raczej w sposób przestrzenny, w danym momencie czasowym, niż jako sekwencję czasową". Przepaść pomiędzy teraźniejszym (czasowym) sposobem odczytania Ulissesa lub Ziemi jałowej a idealnym, którą dostrzega Frank, należy do najbardziej problematycznych aspektów jego książki. Przepaść tę on sam musi zignorować, aby udowodnić założoną tezę. [...] Koncepcja formy przestrzennej [zaproponowana przez Franka - I. T.] [...] jest dokładnym modelem zamkniętego autotelicznego tekstu ${ }^{33}$.

Metafora przestrzeni wyniesiona od Lessinga, a wykorzystana przez Franka na gruncie interpretacji literatury modernistycznej została przez Murraya Kriegera zastosowana do całości poezji. Badacz koncentruje swoją uwagę na tych sposobach, dzięki którym wiersze zajmujące się w szczególności trójwymiarowymi przedmiotami potrafią zaprezentować swoją tak formalną, jak i językową samowystarczalność. Tak Davidson pisze referując poglądy Kriegera:

Poeta może zakomunikować swą świadomość statusu wiersza jako przedmiotu, wykorzystując metafory pochodzące ze sztuk plastycznych; może też przekształcić ruch liniowy używanego języka w bezczasową przestrzeń Eliotowskiej chińskiej wazy z „Burnt Norton” lub Keatsowskiej greckiej urny. Krieger opiera swą tezę na pojęciu ekphrasis - użycia literatury jako imitacji dzieła sztuki plastycznej. „Przedmiot imitacji jako dzieło przestrzenne staje się metaforą czasowego dzieła, które stara się uchwycić ten moment w swej czasowości.

${ }^{31}$ M. D a v i d s o n, Ekphrasis a postmodernistyczne wiersze-obrazy. W zb.: Estetyka w świecie. Wybór tekstów. T. 3. Red. M. Gołaszewska. Kraków 1991 (przeł. P. M ró z, A. W a r m i ń s k i ).

32 Ibidem, s. 44.

${ }^{33}$ Ibidem. 
Dzieło przestrzenne zamraża dzieło czasowe, nawet jeśli to ostatnie stara się uwolnić od przestrzeni" ${ }^{34}$.

Do szeregu przedstawionych przed chwilą propozycji reinterpretacji pojęcia ekfrazy, których zaprezentowanie wydaje mi się konieczne w momencie konfrontacji z tekstem Eulalii, chcę dołożyć jeszcze jedną. W propozycji Jana Elsnera odnajdujemy narzędzia psychoanalityczne ${ }^{35}$. Objaśniając swe spostrzeżenia, badacz przywołuje nazwiska Sigmunda Freuda i Jacques'a Lacana. Wyjściowe założenia Elsnera są dwa. Po pierwsze przyjmuje on, iż ekfraza skonstruowana jest wzdłuż dwóch osi: osi wizualnej, tworzącej się między widzem, obiektem ekfrazy a mową stanowiącą rodzaj zapisu tego, co ujmowane przez oś słowną; oraz osi słownej powstającej między mówcą, audytorium a mową, która w tym wypadku jest określana przez Elsnera jako środek komunikacji. Taki ostry podział został dokonany, jak mi się wydaje, dla uchwycenia głównych elementów stworzonego schematu, zarówno bowiem oś wizualna, jak i oś słowna mają wkodowane napięcie między patrzeniem (widzeniem obrazu) a mówieniem (zwracaniem się do audytorium). W wyodrębnionych osiach to napięcie jest jednak różnie rozłożone. Oś wizualna opisuje bezpośrednie patrzenie (spojrzenie) dostępne twórcy ekfrazy na obraz, a podskórnie dotyka również kwestii mówienia o nim, oś słowna to bezpośrednie mówienie o obrazie, ale należy także pamiętać, że oś ta wiąże się z relacją patrzenia, spojrzenia na obraz kierowanego przez słuchaczy. W ten sposób mowa, ekfraza na całej przestrzeni schematu odgrywa podwójną rolę: „wyraża 〈medianes〉 w słowach obraz widzianego obiektu oraz ustanawia dialog między mówiącym i słuchającym" (E 68). W tej konstrukcji dla mówiącego (patrzącego) zarówno obiekt, jak i słuchacz (patrzący) jest Innym.

Drugie założenie dotyczy psychoanalitycznego rezonansu, jaki wywołują dwie główne cechy określające istotę ekfrazy, czyli (wspomniane już przeze mnie) opisowość i enargeia. Zdaniem Elsnera, ekfraza charakteryzowana przez te dwa elementy -

zajmuje się celową manipulacją wyobraźnią i pożądaniem, zarówno mówcy, jak i słuchaczy. Ekfraza działa zawsze w sferze wyobrażeń, w tej sferze, z którą sublimacja i przeniesienie związane są najsilniej. [E 68]

Freudowską psychoanalizę wprowadza Elsner w swój model ekfrazy, posługując się zaproponowanym przez autora Objaśnienia marzeń sennych sposobem działania dowcipów tendencyjnych, które oprócz rozśmieszenia mają jeszcze dodatkowe zadania. W zbudowanym przez Freuda schemacie dowcipy obsceniczne cechują się triangulacyjnym układem, w jakim zawiera się opowiadający (mężczyzna), osoba, do której odnosi się nieprzyzwoita historia (kobieta), i słuchający (ponownie mężczyzna). Cel takiego dowcipu stanowi wytworzenie uczucia rozkoszy, natomiast tym, co je wywołuje - jest nieustępliwość kobiety wobec ponawianych zalotów opowiadającego. Kobieta w owym układzie jest obnażona, ale i pominięta. Relacja rozmowy dotyczy dwóch mężczyzn, kobieta okazuje się tylko

${ }^{34}$ Ibidem, s. 45.

35 J. E $1 \mathrm{~s}$ n e r, Patrzeć i mówić. Ekfraza w ujęciu psychoanalitycznym. Przeł. W. M i c h e ra. „Konteksty” 2006, nr 1. Dalej do pozycji tej odsyłam skrótem E. Liczby po skrócie oznaczają stronice. 
jej przedmiotem, nigdy zaś aktywnym uczestnikiem. Ale z drugiej strony - jak za Freudem zauważa Elsner - to milcząca kobieta wymusza powstanie całej konstrukcji. Tak więc pierwotna faktyczna obecność kobiety wciąż jest faktyczna, ponieważ „kobieta - mimo że nieobecna - oddziałuje jednak onieśmielająco na relacje mówiącego i słuchającego [...]" (E 69).

Ten Freudowski model Elsner w prosty sposób przekłada na grunt retorycznej ekfrazy. Pierwszą osobę z modelu Freuda stanowi tu autor ekfrazy (mówca), trzecia osoba to słuchacze (czytelnicy), natomiast odpowiednikiem kobiety - drugiej osoby - jest dzieło sztuki, które (podobnie jak kobieta) milczy lub szybko znika, jednocześnie wciąż onieśmielając i oddziałując, wywołując ekfrazę.

Definiując oś wizualną, Elsner sięga po Seminarium XI Lacana z 1964 roku. Dla Lacana niezależna podmiotowość zlokalizowana jest w świecie, w którym stanowi ona tak samo podmiotowość patrzącą, jak i obiekt oglądany. Patrzenie, spojrzenie warunkuje bowiem egzystencję, jest pierwotne w stosunku patrzącego, naznaczone autonomicznością. Patrzący wyobraża sobie jedynie, że to od niego zależy, na co patrzy. Spojrzenie jednostki i spojrzenie świata to nie to samo. Moje spojrzenie, spojrzenie podmiotowego Ja jest możliwe tylko z jednego punktu, świat ogląda mnie zewsząd. Konsekwencję tej relacji, zdaniem Lacana, stanowi błędne wyobrażenie, że obiekt, na który patrzymy, jest zależny od nas, podczas gdy tym, od czego zależy fantazm, tym, co utrzymuje obiekt w przestrzeni istnienia, okazuje się spojrzenie. Podmiot traci kontrolę, jest bierny, bo jedynie, jak pisał Lacan: „dzięki [...] światłu w głębi mojego oka coś się maluje" (cyt. za: E 71), i jest dodatkowo uprzedmiotowiony, bo staje się obiektem spojrzenia świata i poprzez to spojrzenie istnieje. Podmiot traci władzę nad spojrzeniem własnymi oczami na ten świat, które stanowi fundament utwierdzania własnej tożsamości, konfrontacji ze światem.

Proces patrzenia jest zatem procesem pożądania 〈desire $\rangle$ wyobrażonego obiektu (obiektu w umyśle patrzącego), usuwającego stale realny obiekt (będący nie tam, gdzie patrzący spodziewał się go zobaczyć); pożądania bez końca zawodzącego, podobnie jak zawodzi spotkanie obu tych obiektów - wyobrażony, niewspółmierny z Realnym, pozostaje zawsze nieosiągalny. Jak Lacan zawsze powtarza: „To, na co się patrzy, jest tym, czego nie daje się zobaczyć”. [E 72]

Przekładając rozważania Lacana na dynamikę ekfrazy retorycznej, Elsner spostrzega, że retoryczne wystąpienie aranżuje sytuację, w której mówca jest na scenie oglądany przez widownię. Jego wypowiedź, mimo że pozostaje pod jego kontrolą, jest obiektywizowana przez spojrzenie. Zależność ta nie zmienia się z chwilą publikacji i stworzenia pozoru istnienia wypowiedzi pod nieobecność patrzącego audytorium. Elsner chce wtedy konstruować mówcę jako obiekt sfeminizowany, a więc odczuwający satysfakcję kobiety, która wie, że jest oglądana, pod warunkiem, że nie powie się jej tego.

Proces pożądania - rozumiany przez Lacana jako proces patrzenia - $u$ Elsnera utożsamiony jest z samą ekfrazą. To ekfraza, zdaniem tego drugiego, pełni funkcję obiektu wywołującego pożądanie, czyli tego, co Lacan chce nazywać „objet petit a”. Jest to pożądanie audytorium, by słuchać, pragnienie mówcy, by mówić, oraz pożądanie Innego, „czyli dla mówcy w ekfrazie jego mowa jest usiłowaniem obsłużenia i zaspokojenia słuchaczy pragnących poznać malowidło" (E 76). 
W sukurs tak pojmowanemu Lacanowskiemu pojęciu spojrzenia, rozszerzając to pojęcie dodatkowo o aspekt filmu, idzie Todd McGowan ze swoją książką Realne spojrzenie. Teoria filmu po Lacanie. McGowan analizuje krytycznie koncepcję teoretyków filmu lat siedemdziesiątych sięgających po artykuł francuskiego psychoanalityka Stadium zwierciadta jako czynnik kształtujący funkcję Ja w świetle doświadczenia psychoanalitycznego i przekładających go na rzeczywistość odbioru filmu. Wypracowany przez Lacana termin: ,spojrzenie”, lokalizowali oni po stronie widza i łączyli go z aktywnym podmiotem, z generowanym przez ten podmiot procesem, podczas gdy dla Lacana spojrzenie stanowi obiekt badany z perspektywy obrazu, filmu. Spojrzenie podmiot (widz) napotyka w filmie i to właśnie działanie tego spojrzenia rozbudza pragnienie widza. Ów obiekt - przyczyna pragnienia - jest przez Lacana nazwany ,objet petit a”. Idąc dalej za tokiem rozumowania McGowana, obiet petit a jest luką w pozornie wszechmocnym wzroku podmiotu (widza).

Owa luka oznacza punkt, w którym nasze pragnienie manifestuje się w tym, co widzimy. Nie możemy zobaczyć, w jaki sposób pragnienie zniekształca nasze pole widzenia, jedynie odczuwamy owo zniekształcenie dzięki spojrzeniu jako obiektowi. Tym samym spojrzenie włącza widza w obraz filmowy - widz nie może już pozostawać, jak pisze Metz, ,wszechpostrzegającym” i ,nieobecnym jako postrzegany”36.

Ów punkt, wokół którego organizuje się pole widzenia, który przyciąga podmiot, pobudza jego popęd skopiczny, jest punktem braku sensu. Jednocześnie ów punkt buduje popęd widza na obietnicy odnalezienia sensu, dotarcia do niego, odsłonięcia tego, co niewidoczne. McGowan, próbując wyjaśnić ten złożony problem, przytacza doskonały Lacanowski przykład obrazu Hansa Holbeina Ambasadorowie. Punktem na obrazie skupiającym uwagę widza jest amorficzny obiekt w dolnej części obrazu. Widz, który spogląda wzdłuż linii prostej na dziwny obiekt, nie potrafi go rozszyfrować, dopiero odnalezienie odpowiedniego kąta oglądania obiektu umożliwia rozpoznanie w nim czaszki.

Czaszka w kompozycji całości (opowiadającej o bogactwie ambasadorów) jest symbolem śmierci i przemijania, dodatkowo dla Lacana oznacza ona miejsce spojrzenia, ów punkt braku sensu.

Widz, by zobaczyć obraz, musi się w niego zaangażować, patrzenie z dystansu wiąże się ze zniekształceniem i niemożnością jego odczytania. Czaszka - ślepa plama na obrazie -

Pokazuje wyraźnie wpływ aktywności podmiotu na to, co podmiot widzi na obrazie, ujawnia, że obraz nie jest po prostu czymś, na co się patrzy, i że patrzenie nie jest aktywnością neutralną. Czaszka mówi do widza: „myślisz, że patrzysz na obraz z bezpiecznej odległości, ale obraz cię widzi - uwzględnia twoją obecność jako widza ${ }^{37}$.

Spojrzenie jest zatem punktem na obrazie, w którym podmiot całkowicie podlega obrazowi, owa podległość wiąże się - zdaniem McGowana - z wchłonięciem podmiotu przez obraz.

Lacanowskie spojrzenie nie jest więc wzrokiem widza utkwionym w ekran,

36 T. M c G ow a n, Realne spojrzenie. Teoria filmu po Lacanie. Przeł., wstęp K. M i k u r d a. Warszawa 2008, s. 23.

37 Ibidem, s. 26. 
ale spojrzeniem, w jakim film uwzględnia widza. Film, manipulując spojrzeniem, stwarza przestrzeń, w którą widz (poszukując sensu) może się wpasować.

Elsner zakłada, iż czytanie ekfrazy wymaga jednoczesnego wzięcia pod uwagę Freudowskiej osi mowy na temat obiektu, której wektor skierowany jest ku Innemu, jak i Lacanowskiej osi spojrzenia podmiotu na obiekt. Jak ten układ daje się przełożyć na tekst Białoszewskiego? Zanim postaram się odpowiedzieć na to pytanie, chcę jeszcze na moment sięgnąć po spostrzeżenia Kazimierza Wyki i samego Białoszewskiego.

Wyka, próbując zdefiniować przyczyny swojego zachwytu poetyckim debiutem Białoszewskiego, zwrócił przede wszystkim uwagę na poetycką wyobraźnię autora Obrotów rzeczy ${ }^{38}$. To, co według Wyki urzeka, to umiejętność stworzenia wielostronnej i złożonej relacji między elementami składowymi wiersza. Elementami, które formują przestrzeń funkcjonowania podmiotu lirycznego, jak i konstrukcję poetyczną. Jednak owa wielostronna wyobraźnia jest okiełznana przez świadomy rygor. To rygor - jak sądzę - samowiedzy celu i sposobu. Wyka przypisuje Białoszewskiemu wynalezienie filozofii wielostronności. Filozofii, a więc systemu, ale systemu, który ma wkodowany klucz umożliwiający istotne i liczne przemiany na przestrzeni całej twórczości Białoszewskiego. Jednak przemiany te nie burzą jasności widzenia produktu finalnego. Na wielostronność filozofii Białoszewskiego składa się - zdaniem Wyki - zestawienie elementów decydujących o swoistości humoru, groteski, autoironii, co buduje dystans wobec uczuciowości wprowadzającej dodatkowe napięcie oraz nowatorskiego i odkrywczego widzenia zjawisk ${ }^{39}$.

Poetycka wyobraźnia Białoszewskiego jest - według Wyki - wyobraźnią bardzo malarską. Ogarniając spojrzeniem cały debiutancki tom poety, badacz nie chce ograniczać owej malarskości do bogatej kolorystyki, zdobnictwa czy malowniczości, zatem rozszerza takie pojmowanie o istotny element. Malarskość tej wyobraźni rozumie bowiem tak:

Jest nią w sensie plastycznej słuszności nawet w wypadku nieoczekiwanych i najbardziej paradoksalnych skojarzeń wizualnych, które, nawiasem mówiąc, nie służą Białoszewskiemu, by malować: służą sugestii określonych wniosków intelektualno-filozoficznych oraz, bodaj jeszcze ciekawszych u tego poety, wniosków o charakterze obyczajowo-cywilizacyjnym ${ }^{40}$.

Hierarchizując elementy warsztatu poetyckiego, który Białoszewski ujawniał w Obrotach rzeczy, Wyka kładzie nacisk na występującą w nich słuszność w ukazaniu kształtów, kolorów, linii czy - w ocenie badacza - najtrudniejszą do osiągnięcia w słowie słuszność brył w ruchu. Przy czym przez „słuszność” zdaje się Wyka rozumieć obrazowość, zmysłowość, zdolność do wizualnego przedstawiania. Badaczowi jawi się Białoszewski jako ten, który tworzy słowny obraz nie tylko po to, by przemieniać słuchaczy (czytelników) w widzów, ale po to, by ów słuchacz (czytelnik), stając się widzem, otrzymał intelektualno-filozoficzną i obyczajowo-cywilizacyjną informację, która dodatkowo ustawia go w pozycji dialogu z poetą ${ }^{41}$.

${ }^{38}$ K. Wy k a, Na odpust poezji. W: Rzecz wyobraźni. Kraków 1997.

39 Zob. ibidem, s. 141.

${ }^{40}$ Ibidem, s. 141-142.

${ }^{41}$ Wy k a (ibidem, s. 144) nie ogranicza twórczości Białoszewskiego tylko do obrazów. Zauważa, że poeta obywa się często bez szkicowania obrazu, kreując teksty, które są całkowicie sylogistycznymi wypowiedziami. 
Białoszewski - co mnie najbardziej w wywodzie Wyki interesuje - malarskie widzenie wykorzystuje nie tylko do opisu otaczających go rzeczy czy sytuacji, ale również do zreferowania dzieł sztuki. Daje temu wyraz przywołując przykład Średniowiecznego gobelinu o Bieczy, gdzie według niego:

Kompozycja [...] [obrazów] ku temu zmierza, by obraz skonstruować z kształtów najbardziej podstawowych i zgeometryzowanych, jak z biegiem stuleci nauczyli się świadomie czynić kubiści, jak instynktownie działo się to zawsze w sztuce przedstawiającej, zwłaszcza gdy była ona zarazem - gobelin - sztuką ornamentu i zdobienia ${ }^{42}$.

Kwestię malarskości, relacji słowa do sztuk przedstawieniowych w debiutanckim tomie Białoszewskiego podejmowali również Czesław Miłosz ${ }^{43}$, Michał Głowiński ${ }^{44}$, Jerzy Kwiatkowski ${ }^{45}$, Jan Józef Lipski ${ }^{46}$, Stanisław Dan-Bruzda ${ }^{47}$. Uważam, że można pójść trochę dalej niż recenzujący tom badacze, i posługując się siatką wyznaczników zaproponowaną przez Dziadka, mówić o ekfrastyczności albo o zjawisku ekfrazy szczególnie w kontekście Ballad rzeszowskich otwierających Obroty rzeczy. Sądzę, iż Białoszewski opisując w nich gotyckie rzeźby, świątki, kościoły Rzeszowszczyzny korzysta z tradycji retorycznej, czyli w specyficzny sposób traktuje kwestię malarskości, jak nazywa problem Wyka. Znamienne więc, że autor Rozkurzu swoją poetycką działalność rozpoczyna od uchwycenia relacji pomiędzy słowem a obrazem, rzeźbą, literaturą a innymi sztukami.

W Mówieniu o pisaniu Białoszewski przyznaje się:

Już od lat odbiłem się od opisu malarskości, z malarstwem łączą mnie moje pierwsze wiersze, bo są wprost o malarstwie czy oparte na przeżyciach plas t y c z n y c h. Potem tępiłem w sobie uparcie to, co bywa malarskością przez nadmiar metafor, przez zatrzymanie na opisie, przez rozsmakowanie w wyglądzie. Tępiłem to, żeby dramat (dzianie się) w wierszu szybciej szedł. I żeby był czytelny. Nieraz może do przesady był to dramat mówienia, przerywanie. Mówiłem sobie, że jednym z powodów układania wierszy jest radość nazywania. Więc jeśli grzeszyłem, to w swej dyscyplinie, która ma więcej wspólnego zuchem niż zokiem. Zaws ze uważałem poezję za coś do czytania na głos ${ }^{48}$.

Białoszewski mówi w tym fragmencie o literackim przeżyciu budowanym na przeżyciu, jakie towarzyszy oglądaniu obrazu. We wczesnej twórczości osiągał je poprzez stosowanie rozbudowanych metafor opisujących wygląd i skoncentrowanych na nim. Czy jednak odejście od określonego typu metaforyzowania jest jednocześnie odejściem od obrazu? W roku 1993 w „Teatrze” ukazała się wypowiedź Roberta Glińskiego:

Białoszewski jest niesłychanie filmowy. Herezja? Otóż nie. Zrobiłem kiedyś takie ćwiczenie z Białoszewskiego - małe widowisko telewizyjne. Pół godziny, pod tytułem Każdy w bun-

42 Ibidem, s. 143.

${ }^{43}$ Cz. M iło s z, Dar nieprzyzwyczajenia. Nowy poeta polski. „Kultura” (Paryż) 1956, nr 10.

${ }^{44}$ M. G ło w i ń s k i, Spóźnione uwagi o obrotach rzeczy. „Twórczość” 1957, nr 5.

45 J. K w i a t k o w s k i, Abulia i liturgia. W: Klucze do wyobraźni. Warszawa 1964.

46 J. J. L i p s k i, Stowa dodawane do rzeczy. „Życie Literackie” 1956, nr 27.

47 S. D a n-B r u z d a, O „Obrotach rzeczy” Mirona Białoszewskiego. „Pamiętnik Literacki” 1961, z. 4.

${ }^{48}$ M. Bi ałoszewski, Mówienie o pisaniu. W: Poezje wybrane. Wybór, wstęp ... Nota biograf. J. B a n drow s k a - Wrób le w s k a. Warszawa 1976. Podkreśl. I. T. 
krze w swoim cukrze. Skromny portrecik szarych zjadaczy chleba zamkniętych w betonowym „mrowisku” ${ }^{4}$.

Gliński nie ukrywa fascynacji odkryciem, jakiego dokonał dzięki tej realizacji. Fragmenty wierszy poety ułożyły się w spójną całość, która składała się z konkretnych, prawie naturalistycznych obrazków. Bohaterowie mówiąc utworami Białoszewskiego, nie tracą swojego języka, pozostają w swojej sytuacji: krawiec prasuje, ktoś ogląda telewizję, pije wódkę, dziecko płacze, baba pierze. Wszyscy oni dzielą się swoimi wspomnieniami, „refleksyjkami”. Wiersze autora Eulalii przybrały spójny kształt scenariusza.

Jak to wytłumaczyć? Poezja Białoszewskiego rodziła się z odprysków rzeczywistości, przeżytych przez ,język - kurtyzanę w perłach sztucznych zębów”. Film, jak wiemy, żywi się realnością przedmiotu, ciała, przestrzeni. I dopiero z tej pożywki wyrasta forma, która czasem wynosi na eksponowane kawałki celuloidu w inny wymiar. Na parnas. A więc podobny proces jak u Białoszewskiego - od realnego życia do niebywale oryginalnej poezji ${ }^{50}$.

Poeta pozostaje w obrazie, jednak przeniesienie punktu ciężkości z tego, co wizualne, na to, co mówi, na to, co buduje dramat, ,dzianie się”, na udramatyzowanie powoduje, że przestaje być to obraz malarski, a zaczyna być to obraz filmowy.

Triangulacyjna konstrukcja przyjęta przez Freuda jest na tyle elastyczna, iż umożliwia zamianę ról między pierwszą i trzecią osobą. W tekście drukowanym, którym niewątpliwie jest Eulalia, sytuacja komplikuje się dodatkowo przez pojawienie się autora, który stoi za dwoma rozmówcami.

Narracja trzecioosobowa, która przecież nie jest charakterystyczna dla Białoszewskiego, wyzwala dystans, wyczuwalną granicę pomiędzy rzeczywistością ekstradiegetyczną i intradiegetyczną. $\mathrm{W}$ bardzo prowizorycznym schemacie mamy więc: narratora, czytelnika i świat przedstawiony opowiedziany przez narratora. Jednak, jak zauważyłam na początku, rzeczywistość utworu jest opowieścią o sytuacji, jaka zdarzyła się w czasie przygotowywania scenki Napad na stacji. Gdy wyjść od tej najszerszej, ukazanej przeze mnie ramy, czyli porównania historii z mieszkania Dudy i Mariana do krótkich metraży Chaplina, to można założyć się, że Eulalia jest ekfrazą filmiku Napad na stacji, którego akcję kończy scena napaści na lalę. Schemat Freudowski zaproponowany przez Elsnera zaczyna pracować, jeżeli wprowadzone w niego zostaną trzy osoby. Filmik Napad na stacji będący przedmiotem ekfrazy to druga osoba zestawienia. Słuchacze to, podobnie jak w Imagines Lukiana, czytelnicy tekstu. Jak w ten układ wplata się osoba mówiąca w utworze, czyli narrator?

W momencie gdy filmiki zostały wywołane i skonfrontowane $\mathrm{z}$ pamięcią uczestników, zrodziła się nowa wartość. W naturalny sposób uczestnicy zaczęli komentować obrazy, jakie pojawiły się na ekranie. Przejęli skutkiem tego rolę komentatorów, funkcjonujących w kinie niemym. W swoim działaniu najbliżsi byli

${ }^{49}$ R. G 1 iń s k i, Film z Białoszewskiego. „Teatr” 1993, nr 5.

50 Ibidem. 
jednak - według mnie - japońskim benshi. Krzysztof Loska uważa, że benshi pełnili funkcję współautorów filmu, narratorów i komentatorów ${ }^{51}$. Ich zadaniem było nie tylko tłumaczenie napisów, ale również wzbogacanie obrazu słowem mówionym, opowieścią objaśniającą.

Film w Europie i Stanach Zjednoczonych był narracyjną historią przekazywaną za pomocą ruchomych obrazów. W Japonii współautorstwo benshi w tworzeniu filmików polegało właśnie na konstruowaniu opowieści, fabuły. Benshi, których obecność była silnie uwarunkowana kulturowo, przyczynili się do tego, że japońscy autorzy niemego kina, podejmując się realizacji filmu, kładli nacisk przede wszystkim na komponowanie obrazów, które nie tworzyły całości przyczynowo-skutkowej, nie tworzyły ciągłej narracji. W jakiś sposób przypomina to kręcenie filmików. Ich akcja nie jest oparta na logicznie poprowadzonej narracji, ale wręcz przeciwnie - na onirycznych skojarzeniach. Hiroshi Komatsu i Charles Musser tłumaczą:

„Benshi” przekształcili wizualny język kina w język werbalny, toteż wyjaśnienie znaczenia obrazu filmowego było całkowicie uzależnione od ich spojrzenia ${ }^{52}$.

Filmy, które wyświetlano na początku ery niemej - jak słusznie zauważa Loska - były bardzo krótkie, by przedłużyć kilkunastosekundowy seans, sklejano kilka rolek taśmy lub robiono pętlę, zbudowanie spójnej fabuły pozostawiano benshi.

Czytali oni napisy, wyjaśniali elementy obce kulturowo, ale też przygotowywali dodatkowe dialogi, posługując się rozmaitą tonacją głosu, pozwalającą zróżnicować postacie. Tworzenie i podkładanie dialogu pod obraz nie było formą dubbingu, tylko elementem wielopoziomowej narracji, łączącej epizody, tworzącej swoisty monolog wewnętrzny bohaterów, wypełniającej luki poprzez podrzucenie interpretacji i wyjaśnienia.

Narrator w Eulalii przyjmuje rolę benshi ${ }^{53}$. Podobnie jak japoński komentator - przytacza rozmowy bohaterów burleski Napad na stacji, nazywa, thumaczy i komentuje stany psychiczne bohaterów, interpretuje scenkę, uzależnia spojrzenia słuchaczy od swojego spojrzenia. Równie trudno jak w przypadku japońskiego benshi wytyczyć tu granicę pomiędzy autorem, narratorem i komentatorem.

Trzy osoby Freudowskiego schematu pojawiające się w narracji Eulalii to: czytelnicy-słuchacze, filmik Napad na stacji - przedmiot ekfrazy, oraz mówca-benshi, budowany na stałym napięciu między autorem a narratorem. Warto podkreślić jeszcze jedną rzecz. Mówca, retor głoszący ekfrazę wypowiada ją z reguły w sytuacji nieobecności przedmiotu swej wypowiedzi, jego historia ma doprowa-

${ }^{51}$ K. L o s k a, „Benshi” jako współautor filmu. „Kwartalnik Filmowy” 2007, nr 59.

${ }^{52}$ Ibidem, s. 59. Cyt. za: H. K o m at s u, Ch. Mu s s e r, Benshi Search. „Wide Angle” t. 9 (1987), nr 2, s. 85.

${ }_{53}$ Els n e r (E 77) przypomina, że najbardziej typowym i jednocześnie najbardziej złożonym wzorem literackich ekfraz jest ekfraza, w której mówca pełni funkcję egzegety: „W figurze tej widz zostaje skonfrontowany z obrazem, ale ponieważ nie potrafi należycie go zinterpretować, nie doznaje satysfakcji. Wobec tego niepowodzenia na pomoc przybywa egzegeta, zwykle w pedagogicznej/ pederastycznej postaci starszego mężczyzny, który przystępuje do tłumaczenia obrazu". W interesującej Elsnera optyce głos mówiącego jest poszerzeniem objet petit a - słownego opisu (czyli tak naprawdę ekfrazy). O ile w relacji: obraz-mówca-widz, mówca to egzegeta, w relacji: film-mówca-widz, mówca to benshi. 
dzić do tego, że słuchacz zobaczy to, co mówca przekazuje. Jednocześnie ekfraza nie wyklucza sytuacji, jaką przedstawił Lukian w dziele $O$ sali wykładowej (zob. E 69), gdzie przedmiotem wypowiedzi retorów jest sala wykładowa. Sytuacja, w jakiej znajduje się benshi, wymusza współwystępowanie słowa i obrazu, benshi pojawia się na tle obrazu, działa z obrazem. Słowa benshi są więc bezpośrednio weryfikowane przez spojrzenie słuchaczy. Patrzenie, słuchanie, mówienie i sprawdzanie dokonują się jednocześnie. Freud wspomina o pominięciu kobiety (czyli dla nas dzieła sztuki albo burleski Napad na stacji) w sytuacji dowcipu tendencyjnego, przy czym pominięcie nie zakłada jej nieobecności. Kobieta może być zarówno fizycznie obecna, jak i nieobecna podczas dialogu mężczyzn.

Zdaniem Elsnera, zasadniczym działaniem, jakiemu podlega przedmiot ekfrazy, jest jego feminizowanie, którego dokonuje mówca poprzez pominięcie i obnażenie dzieła sztuki. Jako przykład podaje Obrazy Lukiana, gdzie opis, ekfraza kobiety została skonstruowana $\mathrm{z}$ ekfraz wybranych fragmentów najsłynniejszych posągów kobiecych. Rezultatem tak skonstruowanej wypowiedzi jest właśnie odsłonięcie i podwójne pominięcie.

Po pierwsze, traci swą własną postać opisana w ten sposób kobieta: ukazuje się jako osobliwy patchwork, poskładany z fragmentów kanonicznych rzeźb (głowa Afrodyty Knidyjskiej Praksytelesa, policzki i czoło z ateńskiej Afrodyty w ogrodach Alkamenesa, nos z Ateny Lemnijskiej Fidiasza, itd.). Po drugie, same te obiekty - wybrane do odegrania ekfrastycznej roli oksymoronu: doskonała, kanoniczna piękność, a zarazem indywidualność - zostały tu rozczłonkowane. [E 69]

Białoszewski w Eulalii podał opis trzech filmików Napad na stacji. Pierwszy to ten, który przedstawił Marian, drugi to ten, który został wygrany przez aktorów, trzeci - kończący się napaścią na Eulalię. Czy coś je łączy? Tak. To trzy etapy powstawania filmu: scenariusz, praca na planie i gotowy utwór oglądany na ekranie. Całość więc filmiku jest zaprezentowana poprzez opis elementów i podobnie jak kobieta w Obrazach, która zaistniała dzięki fragmentom autonomicznych rzeźb, tak i filmik został opowiedziany w wyniku określenia różnych porządków.

Filostrat Starszy w księdze I Obrazów wyjaśnia:

Istnieje wiele form rzeźb - rzeźba właściwa, czyli modelowanie i naśladowanie w brązie, i dzieła tych, którzy kują w ligdyjskim lub paryjskim marmurze, i rzeźba w kości słoniowej, i, na Zeusa, także sztuka rzeźbienia w cennych kamieniach jest sztuką plastyczną, zaś malarstwo jest naśladowaniem przy pomocy barw; i nie tylko posługuje się ono barwami, ale ta druga dziedzina sztuki mądrze dokonuje tym jednym tylko środkiem działania więcej niż tamta jej wieloma środkami. Odtwarza ona bowiem światło i cień, a także pozwala widzowi po wyglądzie rozpoznać człowieka, który jest wściekły, i tego, który martwi się lub cieszy ${ }^{54}$.

Białostocki w krótkim komentarzu do tego fragmentu tekstu zauważa, że stworzone przez Filostrata porównanie rzeźby i malarstwa ustanawia początek

${ }^{54}$ Myśliciele, kronikarze i artyści o sztuce, s. 125. R. P o p o w s k i trochę inaczej thumaczy ten fragment w komentarzu w Obrazach F i lo strat a S tars ze g o (Przeł., wstęp, komentarz, przypisy R. P o p o w s ki. Warszawa 2004, s. 92): „Wiele jest rodzajów plastyki, bo najpierw samo lepienie, potem odtwarzanie w brązie, ociosywanie lygdyńskiego lub paryjskiego marmuru, rżnięcie w kości słoniowej, a wszak rytownictwo - na Zeusa - też jest plastyką. Malarstwo natomiast zestawia kolory, jednak polega nie tylko na tym. Już samym zestawieniem więcej ono potrafi niż tamta sztuka, choć i ona wiele ma rodzajów. Przecież pokazuje cień i rozpoznaje spojrzenie: inne człowieka oszalałego, a inne cierpiącego lub zadowolonego". 
popularnego później konstruowania estetyczno-literackiego porównania sztuk, tzw. paragone . $^{55}$.

Znamienne, że podobnego zabiegu włączenia rzeźby w opowieść o obrazie filmiku dokonał również Białoszewski. Eulalia, która stała się jednym z najważniejszych rekwizytów w filmikach, była wykonanym z masy papierowej manekinem. Imię manekinowi-rzeźbie nadał Białoszewski. Lalę wykonała Buraczewska, dbając o jej naturalne ludzkie proporcje, ubierając w suknię z kawałków kolorowego materiału. Podobnie jak ta opisana w prozie, Eulalia z Żoliborza ma perukę, którą rzeźbiarka nabyła kosztem poważnych wyrzeczeń (o czym Białoszewski skrupulatnie informuje czytelnika prozy). Artystka usadowiła ją na sfatygowanym nieco, antycznym krześle. Eulalia wyróżnia się na tle innych rzeźb stworzonych przez Buraczewską. Surrealistyczna wyobraźnia podsuwała jej pomysły na rzeźby wykonane z fragmentów mebli, luster, sznurów, odznaczające się intensywną barwą, które artystka nazwała meblotworami, lub na inne duże i ciężkie gliniane struktury, które powstały w czasie jednego z plenerów w Orońsku.

Opowieść mówcy (benshi) rozpoczyna się od przedstawienia bohaterów burleski. Eulalia jest pierwszą pojawiającą się postacią. Mówca informuje słuchaczy, że Eulalia „siedzi bez najmniejszego ruchu”, gdy Marian i Duda, przenosząc, ujmują ją z dwóch stron i sadzają na ławce w przedpokoju, ona „Uśmiecha się w niezmienny sposób" (B 291). Kiedy pojawili się goście i witali się z nią, ona „Nie wyciągnęła ręki, sztywno siedziała w mroku”. Pan Ursyn doszedł więc do wniosku, że ,jest nieruchoma”, na pytanie niewidomej Jadźwinki odpowiada, że w mieszkaniu „Jest jedna osoba, ale nieżywa”. Gdy Jadźwinka dotknęła Eulalii, skomentowała: „Bardzo dobra, chociaż twarda” (B 292). Wszystkie te wyłowione z toku opowieści elementy opisujące Eulalię podkreślają jedną cechę, otóż niezmienność, trwałość. Jak się okazuje, owa niezmienność i trwałość wynika z tego, że Eulalia jest rzeźbą. Duda, opowiadając o jej powstaniu, mówi, że wiązało się ono z dużym trudem i mozołem naklejania warstwy na warstwę. Eulalia ma perukę i biżuterię, można więc z tego opisu wnosić, iż rzeźba wydaje się bliska w swojej formie manekinowi.

Białoszewski, wplatając w opowieść o filmowym obrazie opis Eulalii-rzeźby, idzie tropem swego klasycznego poprzednika. Wytycza jednak nieco inny szlak. O ile Filostrat dość wyraźnie różnicuje te dwa sposoby wypowiedzi artystycznej, znacznie wyżej wartościując malarstwo, o tyle Białoszewski stara się zatrzeć granice między rozmaitymi formami przedstawienia. Jakby podkreślając to, że wszystkie są równie złudne, a jednocześnie ujawniając, że nie są one w stosunku do siebie antagonistyczne, więcej - wzajemnie się dopełniają. Eulalia staje się jedną $\mathrm{z}$ bohaterek-aktorek filmiku i okazuje się głównym motorem napędzającym emocjonalną maszynę rozgrywającej się na planie burleski. Konsekwencją jest ekfraza w ekfrazie. Ekfraza filmiku Napad na stacji funkcjonuje równocześnie jako ekfraza rzeźby wykonanej przez Buraczewską i zatytułowanej Eulalia.

Sfeminizowanie rzeźby dokonuje się w sposób dosłowny. Mówca, narrator, opowiadając o Eulalii, nadaje jej cechy kobiety. Ukazana przez mówcę zazdrość kobiet i zafascynowanie Ursyna rzeźbą pozwalają przypuszczać, że jest ona niezwykle piękna. I odwrotnie, jak ma to miejsce we wspomnianym przez Elsnera

${ }^{55}$ Myśliciele, kronikarze i artyści o sztuce, s. 130. 
opisie kobiety przedstawionym w Obrazach Lukiana, gdzie bezbronny wobec gorgonicznego piękna Lykinosa, by mu sprostać, prezentuje niewiastę jako złożenie fragmentów najsłynniejszych kobiecych posągów, tu rzeźba konstruowana jest z elementów żywej kobiety. Jednak podobnie jak Lykinos ,zobaczywszy cudownie piękną kobietę, wyznaje, że nieomal »w głaz się zamienił, osłupiał z podziwu«, czyli - że sam stał się dziełem sztuki” (E 69), Ursyn również „Stanął jak wryty” (B 292), przekształcił się więc w płaskorzeźbę, dzieło sztuki. Wprowadzenie aspektów kobiecości podważa początkową trwałość i niezmienność Eulalii. Eulalia transformuje się, rozpada się w opisie na rzeźbę (lalę, manekina) i kobietę, w której zakochał się Ursyn i o którą są zazdrosne inne kobiety. Transformacja, brak ustabilizowania w znaczeniu stanowi jednocześnie pominięcie, nie mamy bowiem możliwości dotarcia do jej własnej postaci, bo ta rozpada się w opisie na wykluczające się elementy. Zarazem te wykluczające się elementy są wyłącznymi, danymi nam przez mówcę, wskazówkami, które scalają się w Eulalię. Oprócz tej podwójnej roli lalki i kobiety Eulalię należy rozpatrywać jeszcze w jednym aspekcie, otóż w przestrzeni twórczości literackiej Białoszewskiego staje się ona synonimem filmikowania. Dzieje się tak, ponieważ jest tytułową bohaterką jedynego utworu poświęconego w całości filmikowaniu. W innych (Bielany czy Majowe przejścia) filmikowanie stanowi problem poboczny, będący dopełnieniem głównego nurtu.

Pominięcie wiąże się również z tym, że przedmiot ekfrazy milczy. W przypadku ekfrazy klasycznej milczenie jest naturalną konsekwencją poczynionych założeń, retor ma oprowadzać wokół przedmiotu swego opisu w taki sposób, by słuchacz/widz go zobaczył. Tropienie znaczeń, interpretacja leży po stronie mówcy. Kiedy na planie pojawia się Ciacia - ostatnia z mających zagrać w filmiku - po głośnych powitaniach i monologach zwraca się do Eulalii: „Ach, co to za nowa piękność, mów o sobie...” (B 293).

Twórcą każdego dialogu jest benshi, czyli mówca ekfrazy ruchomego obrazu, pytanie Ciaci jest więc pytaniem mówcy, który wydaje się bezbronny wobec tajemniczości Eulalii. Interpretacja to stawianie pytań dziełu, z którym się mierzymy. Wszyscy pojawiający się do tej pory wypowiedzieli swoją opinię dotyczącą Eulalii, każda z nich była jednak na tyle enigmatyczna, że nie pozwoliła zamknąć opisu, uspójnić go. Benshi szuka ratunku w samej rzeźbie, chce, żeby to ona sama siebie zinterpretowała. Eulalia milczy. To, co następuje później (zazdrość kobiet, zauroczenie Ursyna), jest wynikiem interpretacji, odczuć, które bohaterowie żywią wobec dzieła, rzeźby, czyli tak naprawdę samego benshi szukającego sposobu podejścia do rzeźby, kluczącego różnymi drogami. Eulalia zniknęła, wyniesiona przez Ursyna, nie zostawiając odpowiedzi.

Ekfraza w modelu triangulacyjnym Freuda (podobnie jak sprośny dowcip) jest tendencyjna, jej zadanie nie polega tylko na zmianie kodów czy sprawieniu przyjemności słuchaczowi. To bardziej sposób zbliżenia - Elsner, posługując się terminologią Freuda, wypowiada się o sojuszu - mówcy i słuchacza „w strukturze relacji określonych przez ich wspólne wyłączenie opisywanego przedmiotu [...]" (E 70-71). Białoszewski wspomina o porozumieniu i jako przykład podaje opracowanie przez siebie fragmentów z IV części Dziadów Mickiewicza w konwencji opery, które przygotował dla Teatru Osobnego ${ }^{56}$.

${ }^{56}$ M. B i a ło s ze w s k i, O tym Mickiewiczu, jak go mówię. „Odra” 1967, nr 6. Swoją drogą, 
Elsner, przenosząc założenia Lacana na grunt teorii ekfrazy, zwraca uwagę na sytuację mówcy narażonego na spojrzenia słuchaczy. Podobną sytuację bardzo łatwo odnaleźć w konwencji, w pomyśle na sztukę Białoszewskiego. Poeta twierdzi przecież, że prawdziwa twórczość, akt literacki realizuje się w mówieniu, stąd jego kolejne eksperymenty z działającym, odczytanym słowem ${ }^{57}$. Eulalia ma więc wkodowaną w swoją strukturę potencjalność rozszyfrowania jej przed audytorium, przed spojrzeniem widzów. Potencjalność musi wiązać się z odpowiednim przygotowaniem tekstu, który będzie sprawdzał się w głośnej realizacji. Idzie przede wszystkim o problem rytmu i przeżycia ${ }^{58}$. Co więcej, drobiazgowe polecenia formułowane przez retorów, a dotyczące sposobu zachowania się mówcy przed słuchaczami są również naturalnym elementem twórczości Białoszewskiego, wypływającym, z jednej strony, właśnie z przekonania o oralności literatury, z drugiej - z teatralnego doświadczenia poety. Rodzi się tu jeszcze jeden aspekt. Otóż spojrzenie widza skupione na mówcy jest jednocześnie założeniem istnienia widza oglądającego filmikowanie. Piętno prywatności filmików zamyka je w jakimś sensie na widza z zewnątrz, zabawowo-intymny charakter ogranicza pojęcie widza do pojęcia uczestników. Eulalia, której pierwodruk ukazał się w dwutygodniku „Film”, potem zostaje włączona do tomu Przepowiadanie sobie, staje się swoistym ujawnieniem, jakiego dokonuje Białoszewski, umieszczona w polu, jakie tworzy definicja ekfrazy czy zjawiska ekfrastycznego, wypełnia brak, znosi pominięcie widza w Snach pięciu osób.

Mówca ekfrazy (zjawiska ekfrastycznego) pt. Eulalia jest twórcą współczesnym, ma więc świadomość czekającej go porażki, jeszcze nim podejmie się próby przełożenia obrazu na słowo. Dokonuje zatem pewnego zabiegu, wyszukuje w konstrukcji filmiku, obrazu te elementy, które mogą istnieć w słowie, i za pomocą słowa je przedstawia, nie zmienia kodu. Układa więc krótkie streszczenie (scenariusz) filmiku, referując go za Marianem. Potem opowiada o realizacji filmiku, jednak wypowiedź konstruuje nie z perspektywy Mariana, który operuje kamerą i który mógłby wytłumaczyć czytelnikowi (słuchaczowi), w jaki sposób zaproponowany scenariusz realizuje się w kadrze, narrator trzecioosobowy przedstawia to, co dzieje się na planie, powtarza dialogi bohaterów, komentarze reżysera, bo opis z perspektywy oka kamery narażony jest na fałsz. Ta słowno-słowna struktura wkomponowana jest jednak $w$ ramy ekranu, obrazu poprzez wprowadzenie terminów: ,filmikowanie” i „Napad na stacji”, już na samym początku tekstu. Słuchacz sprowokowany zostaje do wyszukania w tekście elementów pozwalających złożyć w całość filmik. Narrator wykorzystuje potencjalność istnienia słowa w obrazie filmowym, wyzyskuje jego możliwości, by zminimalizować porażkę. Jednocześnie ową słowno-słowną konstrukcję spaja spojrzeniem benshi opowia-

ostatni klasyczny program Teatru Osobnego - o którym poeta wspomina w eseju - oprócz kwestii Mickiewiczowskiego Gustawa zawierał również fragmenty z Wesela S. Wyspiańskiego, które zostanie przywołane w dalszej części mojego wywodu w kontekście pojawiających się w Eulalii kryptocytatów z tego dramatu.

${ }^{57}$ Chodzi tu o wspomniane już nagrywania na taśmę magnetofonową czy realizowane, w czasie „wtorków”, odczytywania fragmentów bądź całości tekstów.

${ }^{58}$ Zob. też B i ało s ze w s ki: O tym Mickiewiczu, jak go mówię; Mówienie o pisaniu. 
dającego czytelnikowi (słuchaczowi) o filmiku (obrazie), którego akcja zbudowana jest wokół realizacji filmiku Napad na stacji. Film opowiedziany przez Białoszewskiego w roli benshi stanowi więc film o powstawaniu filmu.

Czytelnik, słuchacz w Eulalii znajduje się w podobnej sytuacji, w jakiej znalazł się - zdaniem Lacana - widz oglądający obraz Holbeina Ambasadorowie. Podobnie jak widzowie niemieckiego malarza czytelnik w Eulalii poszukuje dostępu do obiektu. Jeżeli w przestrzeni obrazu Ambasadorowie jest to kwestia znalezienia odpowiedniego punktu, właściwego kąta patrzenia, tak w przypadku obrazu Napad na stacji słuchacz poszukuje odpowiedniej perspektywy wobec danego mu w zwielokrotnieniu opisu filmiku. Mówca rozpoczyna od optyki najbardziej pierwotnej, czyli od optyki obrazu, który powstaje w głowie Mariana i którym dzieli się on z przyjaciółmi, przedstawiając schemat scenariusza. Marian nie ma innej możliwości jak tylko kod słowny, by ten obraz opisać. Kiedy narrator opowiada o powstającej na planie scence, korzysta $\mathrm{z}$ tych samych narzędzi, z jakich korzystał bohater diegezy, nie używa perspektywy kamery, przekazuje słowem dziejący się obraz. Dziejący się, charakterystyczną bowiem cechą ekfrazy opowiadającej o statycznym malowidle jest jego dynamizowanie, przekształcanie w narrację akcji ${ }^{59}$. Edward Balcerzan thumaczy:

Bezruchowi malowidła literatura przeciwstawia ruch. Opis obrazu Salome w À rebours „zapomina" ustawicznie o tym, że odnosi się do znieruchomiałych wizerunków ludzi i przedmiotów, staje się opowieścią o jakimś żywym, dynamicznym rytuale. Podobnie dzieje się w licznych wierszach. Co ciekawe: obrazy malarskie w poezji stają się obrazami mówiącymi (Mozaika bizantyjska Szymborskiej, Madonny polskie Harasymowicza). Widowiska inscenizowane w liryce przypominają teatr! Niekiedy upodobniają się do rytuałów, obrzędów, uroczystości. Słowem: malarstwo zmierza tu w stronę synkretyzmu. Wśród owych „inscenizacji” wyodrębnia się także „teatr wyobraźni”, w którym działania i monologi bohaterów z malowideł otwierają obszary fantastyki. Co by się stało, gdyby ożyły kobiety z portretów pewnej szkoły malarskiej? - zastanawia się w jednym z esejów Baudelaire. W poezji: ożywają portrety i pejzaże, i opuszczają ramy malowidła ${ }^{60}$.

Opisywany obraz, zdaniem Balcerzana, otrzymuje od słowa swoisty naddatek. Takim naddatkiem w przypadku filmików, jaki dostaje od ekfrastycznej wypowiedzi, jest słowo, dialog bohaterów, słowo wypowiedziane. Podobnie jak narracja À rebours „zapomina”, że „opowiada” o statycznej płaszczyźnie, tak Eulalia „,zapomina”, że „odnosi się” do niemego filmu. Albo inaczej, opowiadając nam o niemym filmie, włącza słuchacza w przestrzeń kadru, pochłania słuchacza, słuchacz będąc w obrazie, będąc w kadrze, ma dostęp do wypowiedzianego słowa.

Problem spojrzenia to nie tylko problem oglądania filmiku Napad na stacji, ale również problem opisu relacji zachodzących między bohaterami. Białoszewski poświęca wiele uwagi spojrzeniom, jakie są wewnątrz obrazu.

Teraz Duda wzięła się do porządkowania kuchni. Prędko, żeby Ma ri an nie widział.

59 Zob. D. P. F o w l e r, Narrate and Describe. The Problem of Ekphrasis. ,Journal of Roman Studies" t. 81 (1991).

${ }^{60}$ E. B a 1 c e r z a n, Kręgi wtajemniczenia. Czytelnik, badacz, tlumacz, pisarz. Kraków 1982, s. 154. Tekst tego autora nie dotyczy bezpośrednio ekfrazy, ale transmutacji, jednak, jak sądzę, ekfraza jest szczególną formą transmutacji (o czym później). Pisząc o ożywaniu bohaterów malowidła, Balcerzan podaje dalej przykład Kobiet Rubensa W. Szymborskiej, czyli wiersza, który jest niewątpliwe ekfrazą. 
Krzyczałby pod nosem, że to niepotrzebne, ale ona musiała. Coś jej ka zało spiętrzać podobne do siebie przedmioty. [B 291; podkreśl. I. T.]

Spojrzenie stanowi to, co wymusza działanie. Albo inaczej, groźba spojrzenia, które w określonym czasie padnie na Dudę, zwiększa dynamikę jej działania. Duda jest niejako zakleszczona między spojrzeniem a niezrozumiałą koniecznością dokonania czynności, to nadaje rytm jej działaniu. Gdyby informacja o działaniach Dudy zakończyła się w tym miejscu, komunikat byłby jasny. Wypowiedź można by wtedy rozumieć tak, że Marian denerwuje się, gdy Duda w najmniej spodziewanych momentach (zaczynają przecież filmik) zajmuje się czynnościami domowymi. Kolejne zdanie brzmi jak pewien naddatek albo ponownie przywołuje kwestie spojrzenia: „Coś jej kazało spiętrzać podobne do siebie przedmioty” - mówi o spojrzeniu, które wychodzi od obiektu do widza. To obiekty, teraz spiętrzone w jednym punkcie, ale wcześniej rozproszone po kuchni (mieszkaniu) przyciągały Dudę, niczym czaszka z Ambasadorów, zestawem swoich cech. Duda była więc osaczona przez spojrzenia albo zaintrygowana spojrzeniami podobnych przedmiotów, jak Lacan spojrzeniem puszki po sardynkach, i dlatego skupiła je w jednym miejscu.

Spojrzenie jako obiekt byłoby zatem ścigającym patrzeniem Mariana, podobieństwem przedmiotów skupiających uwagę i rozglądaniem się Dudy poszukującej podobnych przedmiotów.

Za pomocą spojrzenia opisana jest również relacja pana Ursyna z Eulalią:

[1.] Stanął jak wryty. Dopiero teraz s p o s tr z e g $\nmid$ damę na ławce. [B 292]

[2.] Trwało to długo. Pan Ursyn siedział między panią Jadźwinką a lalą Eulalią i ją o g 1 ąd a ł. [B 292]

[3.] Pan Ursyn nawrócił twarz ku Eulalii i przyg lą d ał s i ę jej jak przedtem. [B 293]

[4.] Pani Jadźwinka sprawdziła palcami wypukłość godzi.

- Tamtych wciąż nie ma.

- Tamtych? - spytał pan Ursyn przyglądają c s ię Eulalii.

- Mają jeszcze przyjść.

- Właśnie.

Dalej długa cisza z odgłosami i kapaniem. [B 293]

[5.] - Panie Ursynie - cichy głos pani Jadźwinki na tle warkotu kamery - a mną się pan nic nie opiekuje?

- Opiekuje opiekuje - ale zag a pił si ę na lalę. [B 296]

[6.] Cyganka Felunia na próżno z a g 1 ą d a w ukłonach tanecznych panu Ursynowi w oczy i w okulary, tak mu się przecież zawsze podobała. A dziś? On w i d z i tylko Eulalię. Nie pomogło szczypanie go w łokieć przez Ciacię. [B 296]

[7.] Nałożyli Eulalii perukę.

- Znów piękna!

Pan Ursyn zaczął s ię lali przyg ląd ać jak przedtem. [B 297]

[8.] Wtem Pan Ursyn s p o strzegł osaczenie Eulalii. Rzucił się sztywno na ratunek. [B 298 $]^{61}$

Konsekwencją spojrzenia kierowanego przez pana Ursyna na lalę jest działanie.

${ }^{61}$ Wszystkie podkreślenia w cytowanych przykładach - I. T. 
Z jednej strony, owo spojrzenie powoduje słowne działanie Jadźwinki, która, niejako czując to spojrzenie (sama przecież nie widzi), chce odciągnąć uwagę Ursyna od Eulalii. Spojrzenie Ursyna ku Eulalii prowokuje również działanie Ciaci i Feluni. Co więcej, okazuje się, że stosunek Ursyna do innych bohaterów nie jest opisany za pomocą spojrzenia. Pan Ursyn w relacji z Jadźwinką dotyka jej albo jej słucha:

[1.] I poprowadził ją przed siebie, delikatnie popychając [...]. [B 292]

[2.] Po piętnastu minutach spytała cichym głosem:

- Panie Ursynie?

- Słucham? - odwrócił do niej głowę.

- Co się dzieje?

- Ano nic. [B 293]

Relacja z Felunią to gest dawania:

Felunia się skrzywiła. Ale już musiała wydać z siebie uśmiech, bo pan Ursyn podał jej mleko w proszku.

- To dla pani, żeby pani mniej paliła papierosów.

- Dziękuję, och jak się cieszę. [B 294]

Ciacię pan Ursyn z kolei obdarza komplementami:

- Panie Ursynie, mnie się coś też należy, za ducha psa, w moim ogródku.

- A tak tak, bardzo ładny płaszczyk pani sobie wyszykowała i podobna pani w nim do odpowiedniego anioła. [B 296]

Jednak spojrzenie koncentrowane na Eulalii jest działaniem nadrzędnym w stosunku do wszystkich innych. Kobiety zazdrosne właśnie o to spojrzenie doprowadziły do napaści na Eulalię. Wzrok skierowany w niewłaściwą stronę wywołał zazdrość, brak spojrzenia poprowadzonego w oczekiwaną stronę i możliwość jego przyciągnięcia wywołało pożądanie. Co więcej, to właśnie spojrzenie Ursyna powoduje, że Eulalia traci tożsamość, nieustannie się transformuje, oscylując między lalą a kobietą. Niewidoma Jadźwinka, niczym mitologiczny Edyp, odkrywa prawdę o Eulalii:

- Czy tu jest ktoś?

- Jest jedna osoba, ale nieżywa.

- Co pan opowiada? - przelękła się pani Jadźwinka.

$[\ldots]$

- To niespodzianka, pani Eulalia, zagra z państwem.

- Bardzo nam będzie przyjemnie - stwierdził pan Ursyn powoli jak zawsze.

- To nieprawdziwa osoba? - domyśliła się pani Jadźwinka.

- O właśnie, niech pani ją obdotyka. [B 292]

Po tej sugestii Mariana - Duda opowiada o tym, jak powstawała Eulalia.

Transformująca moc spojrzenia Ursyna spowodowała jednak, że Jadźwinka zatraciła pewność o istnieniu prawdy. Z rosnącym niepokojem i zazdrością wsłuchuje się w oglądanie, wpatruje się we wzrok Ursyna kierowany na Eulalię, by w końcu razem z Ciacią i Felunią zaatakować lalę-kobietę.

Skoncentrowane na Eulalii spojrzenie Ursyna splata się chwilami ze spojrzeniami Feluni i Ciaci również utkwionymi w tym punkcie oraz wyczekującym, poszukującym spojrzeniem tej pierwszej bohaterki skierowanym na Ursyna. Jednak centralną postacią skupiającą spojrzenie jest Eulalia, sama naznaczona pominięciem, 
brakiem, bo ona sama nie patrzy, nie ma przypisanego jej spojrzenia. Eulalia przywołując uwagę innych, prowadzi do rozpadu, którego znak stanowi napaść na nią. Jednak Eulalia, w wyniku transformacji, jakiej ulega w oczach bohaterów-aktorów, jest również znakiem porażki spojrzenia. Utrata tożsamości Eulalii, jej podmiotowości to ślepa plama na obrazie, objet petit a. Podobnie jak w przypadku Ambasadorów i Napadu na stację nie można odnaleźć właściwego kąta, pod jakim należy oglądać Eulalię, albo dopuszczenie do głosu wielu punktów obserwacji powoduje, że Eulalia się rozpada.

W strukturze tekstu uchwycone jest jeszcze jedno spojrzenie, mianowicie będące elementem doświadczenia metafizycznego. W toku narracji pojawia się opowieść o duchu psa, którego w pobliżu leśnego domku Ciaci widział pan Ursyn. Jednak o ile spojrzenie na poziomie rzeczywistości empirycznie dostępnej odznacza się pewną ambiwalencją: zawodzi jako narzędzie badania, nie rozstrzyga o tożsamości Eulalii, o tyle ma moc powoływania nowej (fałszywej?) tożsamości. W przestrzeni metafizycznej proces patrzenia wydaje się zupełnie bezradny, bo opiera się na grze pozorów, wiary i abstrakcyjnych znaczeń:

- Tak jakby. Znaczy: tam chodziłem pod parkan i piesek czekał na łańcuchu. Potem znikł. Została pusta buda. I łańcuch. Szereg nocy cisza. I nagle któregoś razu tam dochodzę przez gąszczyk, za parkanem coś się bieli na łańcuchu, coś się trzęsie białego. Podsuwam się, a to białe znika. Spoglądam. A ono bieli się i trzęsie wyżej, na gałęzi. I znów znika. I cisza. [B 295]

W kontekście spojrzeń, o których mowa w tekście, spojrzeń, które są przedmiotem opisu, wydaje się ciekawy jeszcze jeden aspekt. W Tajnym dzienniku poeta przedstawia jeden z wieczorów u Klewinów.

W dniach głodówki protestacyjnej w kościele wypadło nam kameralne kręcenie filmikowe na Żoliborzu. Ada, jej ojciec Eryk, Kicia Kocia i ja. Kicia Kocia zamówiła jeszcze rzeźbiarkę Barbarę Z. Barbara Z. przyszła spóźniona i wzburzona. Zgodziła się zagrać w krótkiej scenie pod tytułem Napad na stacji. Siedzieliśmy z Erykiem i Kicią Kocią we trójkę na ławeczce pod drzwiami sublokatora, drugie drzwi, od łazienki, z napisem „kasa” miały się w pewnej chwili otworzyć i miał z nich wyskoczyć bandyta w masce. Przed kręceniem Barbara Z. nałożyła na siebie czarny słomkowy kapelusz. Wyglądała w tym, siedząc na krześle, poważnie jak starsza pani. Ada jej dała sztuczne dwa rewolwery z papier-maché. Na twarz maskę, taką twarz mniejszą od ludzkiej. Przez to bardzo dziwną. Barbara Z. schowała się w kasie, a na dany znak wypadła z maską na twarzy. Całe swoje zdenerwowanie wpakowała w grę. Robiła świetne gesty. Duża. Podobna do zwalistego oprycha. Sterroryzowała nas, pasażerów, i wzięła się do Kici Koci w blond peruce. Tę blond perukę Kicia Kocia koniecznie chciała dziś mieć dla siebie. Przypuszczalnie właśnie ta peruka zdenerwowała Barbarę Z. Przewróciła Kicię Kocię na podłogę i nawet podduszała ją szalem. Oczywiście, niby w zabawie. [...] Przy tym - jak wspomina Ada - Kicia Kocia gniotła i rozciągała perukę. A Ada drętwiała, że tę perukę zniszczy, a dali za nią aż siedemset złotych ${ }^{62}$.

W powstających między tekstem z dziennika a Eulalia relacjach Białoszewski staje się obrazem samego siebie. Przyległość ukazanych sytuacji ma tu drugorzędne znaczenie. Obraz ze swej natury nie jest mimetyczny, tekst nie jest więc równy tekstowi, tekst jest obrazem tekstu. Ponowienie próby opisu Napadu na stację to chęć zaspokojenia pragnienia uchwycenia obrazu w słowie.

Jako objet petit a w polu widzenia spojrzenie jest punktem, wokół którego organizuje się to pole. Jeśli konkretne pole widzenia przyciąga pragnienie podmiotu, spojrzenie musi być

${ }^{62}$ M. B i a ł o s z e w s k i, Tajny dziennik. Kraków 2012, s. 366. 
w nim obecne jako punkt nieobecności sensu. Spojrzenie przykuwa nasz wzrok, gdyż wydaje się oferować dostęp do tego, co niewidziane 〈unseen〉, do odwrotnej strony widzialnego. Obiecuje odkryć przed podmiotem sekret Innego, ale ów sekret istnieje tylko o tyle, o ile pozostaje w ukryciu. Podmiot nie może odkryć sekretu spojrzenia, a jednak wskazuje ono punkt, w którym pole widzenia uwzględnia pragnienie podmiotu. Jedyne zaspokojenie dostępne podmiotowi polega na krążeniu wokół uprzywilejowanego obiektu (właśnie taki ruch psychoanaliza nazywa popędem) ${ }^{63}$.

Z drugiej strony, sytuacja Białoszewskiego powielającego w dzienniku opis obrazu-filmiku przywodzi na myśl stadium lustra Lacana. Jest bolesnym i bezwzględnym odsłonięciem luki w polu widzenia, bolesnym odczuwaniem zniekształcenia, jakie pragnienie (czyli chęć zamknięcia obrazu w słowie) wywołuje. Przy czym lustro Białoszewskiego, pozwalając odczuć owo zniekształcenie, nie daje zgody, by zobaczyć stopień zniekształcenia obrazu przez pragnienie.

Podobnie jak wcześniej wspomniany Wyka, tak i Balcerzan starając się nazwać relacje, które zawiązują się w między literaturą a innymi sztukami, posłużył się przykładem Średniowiecznego gobelinu o Bieczu ${ }^{64}$. Wyka jednak rozważa obrazowość, malarskość w kontekście wizualizacji elementów rzeczywistości lub dzieła sztuki i wplecenia w tworzący się obrazowy sens dodatkowych wymiarów: filozoficznego, intelektualnego, obyczajowego, cywilizacyjnego, Balcerzan natomiast rozróżnia dwa jakościowo odmienne schematy wyglądowe występujące w poezji Białoszewskiego. Dla badacza czymś wyraźnie innym jest obraz skonstruowany w wierszu Podłogo błogosław niż obraz, jaki pokazuje Białoszewski w Średniowiecznym gobelinie o Bieczu. Różnica polega na stopniu nasycenia „miejsc niedookreślonych" "65. Obraz zarysowany w tekście Podłogo błogosław, wzbogacany o coraz to nowsze detale, kolory, kontury, znaczenia, jest inaczej odbierany, ma odmienny walor niż obraz, który jest jednocześnie wykreowany językowo i zapamiętany „malarsko”. Średniowieczny gobelin o Bieczu wymaga od czytelnika obeznania się z kulturą artystyczną. Obraz buraka i podłogi opiera się na codziennych doświadczeniach czytelnika, dla Balcerzana to typ wiersza, który „milczy o sztuce”, drugi wiersz w tym opozycyjnym układzie jest wierszem „mówiącym o sztuce" 66 , a zarazem projektującym czytelnika aktywnego o określonych kompetencjach, jest wierszem, który funkcjonuje na prawach metatekstu kultury.

Balcerzan rodzącą się relację między obrazem a poezją tłumaczy na gruncie semiologii, używając pojęcia transmutacji:

Transmutacja (tłumaczenie intersemiotyczne) oznacza, że tekst uformowany w granicach jednego systemu (np. malarstwa) i rekonstruowany w materiale innego systemu (np. poezji) traci specyficznie malarskie i uzyskuje specyficznie poetyckie właściwości. Na zastrzeżenie Welleka i Warrena, że „chłód w poezji jest czymś bardzo różnym od wrażenia dotykowego, jakiego udziela marmur, a obrazowa rekonstrukcja bieli też się wybitnie różni od zmysłowego jej postrzegania", trzeba odpowiedzieć: ależ tak! i o to właśnie chodzi. Gdyby efekt poetycki nie różnił się od efektu malarskiego, nie mówilibyśmy o transmutacji, a i sam proceder byłby niepotrzebny: $\mathrm{w}$ jakim celu poeta miałby powtarzać cudze, gotowe efekty? ${ }^{67}$

${ }^{63}$ M c Gow a n, op. cit., s. 24.

64 B a l c e r za n, op. cit.

65 Ibidem, s. 136.

66 Ibidem.

67 Ibidem, s. 142. 
Balcerzan przywołuje Średniowieczny gobelin o Bieczu jako przykład ,autentycznego spełnienia założeń transmutacji” ${ }^{68}$, a idzie mu przede wszystkim o fakt, że wiersz przenosi do literatury pewne wartości dodatkowe. Wartości te autor upatruje w fakcie kwestionowania przez Białoszewskiego zróżnicowania poziomów w przekazie tekstu plastycznego. Tzn. warstwa lingwistyczna referująca proces oglądania gobelinu powtarza jednocześnie proces sporządzania tkaniny gobelinowej. Poziom materialny, czyli fizyczna postawa bytowa tkaniny, gobelinu i poziom rzeczywistości przedstawionej nakładają się na siebie.

„Cynobry obronne na zrębie [...]”69 to trop, który w warstwie lingwistycznej można nazwać „metonimią urządzeń fortyfikacyjnych lub ubiorów ludzi broniących dostępu do jakiejś zamkniętej przestrzeni”. Kiedy traktować ów trop jako rezultat transmutacji odwołującej się do sytuacji odbiorczej, można czytać „cynobry” (w znaczeniu czerwonego barwnika stosowanego w malarstwie, otrzymywanego z siarczku rtęciowego) jako element odnoszący się do poziomu materialnego, natomiast „obronne” i ,na zrębie” jako te, które odnoszą się do warstwy przedstawieniowej. Fakt powtarzalności chwytu wskazuje, że nie jest to przypadek:

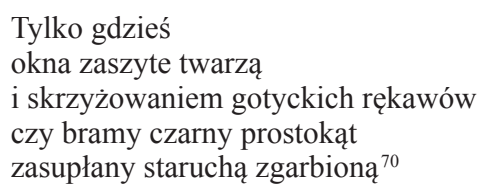

W tym fragmencie badacz dostrzega trzy poziomy, pomiędzy którymi zostaje zachwiana hierarchia i jasność podziału:

Słowa „zaszyć” (zaszyć nićmi jakiś fragment płaszczyzny), słowa „zasupłać czarny prostokąt”, ,skrzyżować” - przedstawiają pracę nad gobelinową kompozycją, która jest spotkaniem materii plastycznej: jej jakości konturowych (krzyż, prostokąt), kolorystycznych (czarny), fakturowych (szyć, supłać). „Oko”, „twarz”, „zgarbiona starucha” uobecniają rzeczywistość przedstawioną. Wreszcie „gotycki”, odnoszący się do trzeciej, najwyższej, ikonologicznej warstwy dzieła plastycznego. Naruszenia układu warstwowego są tu tak ostentacyjne, że - paradoksalnie! - uwypuklają ten układ. Uczą odróżnić warstwy. Przekazują zarazem prawdę psychologii odbioru, kiedy to wzrok - raz ucieka w iluzję obrazu, raz zatrzymuje się na płótnie, gubi się wśród nici, supłów, zaszyć lub pokonuje opór materialnych ukształtowań ${ }^{71}$.

Obok przenoszenia nowych wartości na terytorium literatury transmutacja wiąże się z pewnym ubytkiem. Niedoskonałość języka-pośrednika albo zastosowanie innego kodu w stosunku do tego, jakim posługuje się opisywane dzieło sztuki, powoduje, że jego rzeczywistość może być rekonstruowana schematycznie. $\mathrm{Z}$ drugiej strony, owa zdolność schematycznego uchwycenia pozwala w ogóle na opis dzieła, które jest strukturą dynamiczną i ewoluującą, zmienną. Poezja odtwarza albo postuluje określony stosunek do sztuki (gdyby dzieło było absolutnie pewną i stabilną rzeczywistością, jego opis, rekonstrukcja byłyby niemożliwe, ponieważ to zakotwiczenie wymagałoby zastosowania tego samego kodu).

68 Ibidem, s. 147.

${ }^{69}$ M. B i a ł o s z e w s k i, Średniowieczny gobelin o Bieczu. W: Sprawdzanie soba. Wiersze wybrane. Warszawa 2008, s. 20.

70 Ibidem, s. 23.

${ }^{71}$ B a 1 c e r z a n, op. cit., s. 148. 
Ciekawa okazuje się ambiwalencja sytuacji, w której:

Język-pośrednik ustawicznie przeżywa załamania wewnętrzne, i nie tylko poezja, lecz całość mowy zorientowanej ku sztuce boryka się ze schematycznością, cząstkowością, kłamliwością form werbalnych ${ }^{72}$.

Z drugiej strony, tylko fakt owego wewnętrznego załamania i kłamliwości umożliwia istnienie tej formy poezji oraz dążenie do granicy ideału przystawalności przy jednoczesnym unikaniu jej osiągnięcia, niedopuszczanie do zlania się znaków, a w konsekwencji - zaniku dualizmu, dwupoziomowości sytuacji opisu.

Balcerzan zwraca uwagę na jeszcze jedną dość istotną (i dla mnie) sprawę. Otóż transmutacja przebiega różnie w zależności od tego, czy obiektem jest dzieło werbalne, czy niewerbalne.

O transmutacji właściwej możemy mówić w odniesieniu do systemów niewerbalnych. Natomiast stosunek poezji do przekazu synkretycznego jest zawsze dwuznaczny. $Z$ jednej strony, to stosunek słowa do słowa (gdyż słowo stanowi składnik wypowiedzi synkretycznej). $\mathrm{Z}$ drugiej - stosunek słowa do nie-słowa, do niewerbalnych znaków teatru czy filmu ${ }^{73}$.

Jak jednak Balcerzan zauważa, istnieje możliwość transmutacji sensu stricto nawet w przypadku teatru i filmu, ale pod warunkiem, że utwór komentuje niewerbalne znaki tych sztuk. W kontekście werbalnych i niewerbalnych tekstów główna różnica polega na tym, iż konsekwencją przekładu teatru na poezję jest redukcja tego pierwszego, a konsekwencją przekładu obrazu, kodu plastycznego na poezję jest amplifikacja.

Sądzę, że transmutacja (badająca relację między znakami sztuki na gruncie semiotyki) pozostaje $\mathrm{w}$ jakiejś zależności z interesującą mnie ekfrazą. Ekfraza byłaby pewnym aspektem transmutacji, byłaby taką transmutacją, która przebiega od dzieła sztuki do języka, byłaby ujęzykowieniem doświadczenia innych sztuk (podczas gdy transmutacja bierze pod uwagę również sytuację dewerbalizacji poezji w kodzie innych: muzyki, malarstwa itd., oraz wszystkie możliwe relacje zachodzące między znakami poszczególnych sztuk). Ponadto, jeżeli uważać dzieło sztuki za rzeczywistość stabilną, niezmienną znaczeniowo, to tym samym znosimy pojęcie ekfrazy. Ekfraza jest bowiem czytaniem i interpretowaniem tekstu artystycznego z wyraźnym zaznaczeniem rysu autorskiego. Transmutacja skupia się na znaku, kwestia dzieła sztuki pojmowana jako rzeczywistość absolutna, niezmienna czy też rzeczywistość podlegająca bezustannym przemianom okazuje się drugorzędna. Problem dotyczy wtedy zagadnienia rekonstrukcji dzieła sztuki bądź jej braku. Transmutacja nie koncentruje również swej uwagi na autorze, ale na dynamice przełożenia jednego kodu na drugi.

Niemniej analiza problemu transmutacji dokonana na przykładzie Średniowiecznego gobelinu o Bieczu zdaje się podsuwać pewne rozstrzygnięcia w kontekście Eulalii. Dopatrzył się bowiem Balcerzan w utworze elementów oglądania gobelinu słowem, czyli - jakby chciał tego Elsner - byłoby to spojrzenie pojmowane jako obiekt.

Bardzo zbieżne zresztą ze spostrzeżeniami Balcerzana uwagi poczynił Elsner, przypatrując się ekfrazie Myśliwi Filostrata Starszego. Stwierdza on, że Filostrat

\footnotetext{
${ }^{72}$ Ibidem, s. $150-151$.

73 Ibidem, s. 153.
} 
wyróżnił trzy poziomy, elementy, opisując fascynujący go obraz. Pierwszym jest powierzchnia malowidła pokryta barwną farbą, potem treść malowidła, czyli polowanie na dzika, gdzie statyczna kompozycja przekształca się w narrację, na koniec retor daje nam wykładnię interpretacyjną. Podobnie jak Balcerzan, Elsner zwraca uwagę na fakt, że żaden ze składników obrazu po przekształceniu go w mowę nie zachował swej ,oryginalnej postaci”. Barwniki są przyczynkiem do włączenia wątków mitycznych, opowieść o polowaniu natomiast zostaje tak poprowadzona, iż trudno rozstrzygnąć, które jej elementy mają własne obiektywne źródło w obrazie, a które są wyobrażone i dopowiedziane przez mówcę. Tak więc - porządkując za wywodem Elsnera - „Obraz widziany na poziomie pigmentów nie jest tym samym, który sofista pragnąłby ujrzeć w wymiarze pożądania” (E 75). Wszystkie zatem odpowiedzi, jakie znajduje badacz w obrazie - podobnie jak benshi w Eulalii, kiedy opowiada o rzeźbie - stanowią jego wyobrażenie. Poszczególne składniki, warstwy rozpadają się.

Kiedy Białoszewski w tekście Coś mnie ciagnie zastanawia się nad głównymi elementami niemego kina, wymienia: ruch, rytm i pomysł (,,pomysł za pomysłem, jeden pomysł trwa krótko, już goni następny" ${ }^{74}$ ). Akcja Eulalii nie rozwija się linearnie, jak chociażby w Siostrze Eulalii czy w Majowym przejściu. Jest wyraźnie podzielona na drobne sceny-ujęcia, przez co dramaturgicznie przypomina niemą komedię, w której rytm to efekt następujących po sobie sekwencji. Można wyróżnić 16 takich scenek-ujęć w Eulalii. Białoszewski konstruuje to opowiadanie używając krótkich zdań. Składnia zdania koncentruje uwagę czytelnika na ruchu, na opisie ruchu:

[1.] Teraz Duda wzięła się do porządkowania kuchni. Prędko, żeby Marian nie widział. [B 291] [B 292]

[2.] Duda wbiegła ukośnym krokiem do kuchni. Kończyła stosy. Pies poleciał za nią.

[3.] Dzwonek. Seria. Szczekanie. Wypadł pies z trzeciego pokoju, sam sobie drzwi otworzył i dopadł sucharów. [B 293]

[4.] Wpadła roztańczona, zziajana Felunia. [B 293]

[5.] Dzwonek. Szczekanie psa. Monolog Ciaci od drzwi [...]. [B 293]

[6.] Wleciałam tu, jakbym miała dwadzieścia dziewięć lat, przepraszam, ile ja mam, bo zapomniałam? [B 293]

[7.] Gdzie pan dostał mleko w proszku? - spytała Ciacia rozwiewając robione na drutach treny płaszcza. [B 294]

[8.] Wyleciał z pokoju do towarzystwa z przedpokoju Marian, za nim pies, który coś gryzł i teraz rzygał. [B 294]

Na rzeczywistość przedstawioną będzie się składało to, co przynależy do świata przedstawionego opowiadania. Przy czym podobnie jak w Średniowiecznym gobelinie o Bieczu poziom pierwszy, który stanowi strukturę, porządek filmowy, i poziom drugi są ze sobą w nieustannym napięciu, przenikają się.

${ }^{74}$ M. B i ał o s ze w s k i, Coś mnie ciagnie. „Film” 1977, nr 38, s. 3. 
Główne elementy składające się na narrację interpretującą w Eulalii to: zagadnienie aktora ulalkowionego, problem przeżycia i dialog z Weselem Stanisława Wyspiańskiego.

Przybyłym i nieco zdumionym uczestnikom filmikowania Marian thumaczy obecność Eulalii: „To niespodzianka, pani Eulalia, zagra z państwem” (B 292). Tym samym nadaje jej status aktorki. Marionetka, lalka staje się więc próbą wytłumaczenia funkcji aktora w filmikowaniu. Białoszewski w ten sposób koncentruje wiedzę swojego czytelnika dotyczącą filmikowania na lalce, marionetce, która przejmuje rolę kobiety, a dokładniej: rola ta jest jej dana przez uczestników filmikowania. To oni niczym lalkarze - ale przy użyciu słów i spojrzenia - animują jej działanie, obdarzają ją statusem. Ponadto sami stają się widzami stworzonego przez siebie widowiska, przeżywając skonstruowany według własnego pomysłu scenariusz wydarzeń ${ }^{75}$.

W Eulalii rzeczywistość stanowi integralny element sztuki. Nie jest to jednak rzeczywistość pojmowana mimetycznie. Nie chodzi o udawanie rzeczywistości. To, co dzieje się w mieszkaniu Mariana i Dudy, nie ma być teatrem iluzyjnym, gdzie - jak piszą Białoszewski i Stefański: „Nawet fantazja udaje tam rzeczywistość. Kompozycją dramatu rządzą prawa życiowe lub - co najmniej - psychologiczne"76.

Scenką w salonie rządzą prawa będące krańcowym przeciwieństwem teatru iluzyjnego ${ }^{77}$, prawa Teatru na Tarczyńskiej. Teatr Białoszewskiego charakteryzuje się wieloznacznością postaci scenicznych, sytuacji, rekwizytów. Tutaj tę wieloznaczność wyraża Eulalia: lalka-kobieta. Tak skonstruowana nie zaprzecza sobie samej. Nie jest próbą mimetycznego przedstawienia rzeczywistej lalki w sztuce, takie przeniesienie groziłoby jej unicestwieniem. Lalka-kobieta nie bierze swoich idei z tradycyjnego teatru lalek, dążącego do jak najdoskonalszej iluzoryczności. Eulalia podąża szlakiem wyznaczonym przez Wiwisekcję:

Teatr „rąk i przedmiotów”. Nie teatr lalek - pomimo pozorów! W jednej ze sztuk - palce występują w kostiumach jako bohaterowie dramatu, nie przestając być jednak palcami. Mówią do siebie „doktorze Kciuku”, ,doktorze Prawy Serdeczny” itd. W innym wypadku - lalka nie jest postacią graną przez lalkę, ale sobą - przedmiotem zwanym lalką ${ }^{78}$.

Twórcy Teatru na Tarczyńskiej w konstruowaniu postaci przez aktorów zwracają uwagę na budowanie stałego napięcia dramatycznego między planem pierwszym, przedstawiającym, a planem przedstawianym, „Czyli między aktorem a odgrywaną przezeń postacią" 79 . Eulalia (słowna i obrazowa) ilustruje właśnie owo napięcie. Tyle że w narracji jest ono wyrażone słowem, próbą zdefiniowania lalki-kobiety, w filmiku - za pomocą gestu Kiełkiewicza i gestu animatorki marionetki. Eulalia stanowi doskonałe wyobrażenie, umowność człowieka (podobnie

75 „Przeżycie” jest niebywale istotną kategorią dla B i a ł o s z e w s k i e g o (O tym Mickiewi$c z u$, jak go mówię) w kontekście jej odbioru. Na podobnej zasadzie łączenia statusów widza i aktora funkcjonowały filmiki w momencie, gdy je tworzono. Białoszewski nie zakładał publicznego pokazu efektu tych zabaw.

${ }^{76}$ M. B i ało s ze w ski, L. S te fań ski, Sztuka przedstawiania. Wnioski z Tarczyńskiej. W zb.: Świadomość teatru. Polska myśl teatralna drugiej połowy XX wieku. Red. W. Dudzik. Warszawa 2007, s. 17.

77 Zob. ibidem, s. 18.

78 Ibidem, s. 20-21.

${ }^{79}$ Ibidem, s. 18. 
jak palce z Wiwisekcji), ponieważ człowiekiem nie jest. To ona uruchamia przetwarzanie rzeczywistości. Aktorzy filmikowania poddając się temu, „dosławniają czas, miejsce, akcję, komplikację”, czyli prezentują „,rzeczywistość jako artystkę"80. Rozmawiając i działając, napędzają, podwyższają wartość przeżycia ${ }^{81}$. Doprowadzają je do takiej intensywności, że zmieniają strukturę, zasadę działania świata przedstawionego. Poziom rzeczywistości utworu (,Za chwilę przyjdą znajomi na filmikowanie. On kręci, oni grają", B 291) staje się poziomem sztuki utworu aktorzy zrealizowali przecież założenia scenariusza Mariana: był napad, walka, wyrywanie. Rzeczywistość i sztuka „zaczepiają” o siebie.

Skoro jednak mowa o przeżyciu - aktorzy, mimo że przenoszą się z poziomu rzeczywistości w strukturę filmiku, nie wchodzą w rolę, aktor nie staje się bohaterem. Aktor w filmiku, podobnie jak w teatrze Białoszewskiego: „nie przedstawia postaci scenicznej; on podkreśla, że ją przedstawia. Nie podszywa się, lecz relacjonuje, przytacza sytuacje, rozmowę, nastrój. Aktor pozostaje aktorem" 82 .

Duda pozostaje Dudą, Ciacia - Ciacią... Co się jednak dzieje z Eulalią? Lech Emfazy Stefański zapytany o początki Teatru na Tarczyńskiej, wskazał na artykuł Edwarda Boyé znaleziony w „Wiadomościach Literackich” z 1926 roku. Będąc w Paryżu, Boyé odwiedził Le Théâtre Universitaire Art et Action. We wspomnianym artykule pisał, cytując twórcę przedstawienia:

Aby zaś nie sfałszować charakteru dzieła, wprowadziłem na scenę manekiny. Każdy aktor, ubrany na czarno, ginął całkowicie na tle czarnego jedwabiu. Widzialne były tylko pajacyki, poruszane przez niosących je na sobie aktorów. Szło nam o to, aby artysta uczłowieczał manekina, a nie człowiek żywy stawał się manekinem ${ }^{83}$.

Eulalię uczłowiecza słowo, uczłowiecza gest, uczłowiecza spojrzenie. To definiowanie wszakże, aby pozostać wiernym założeniom teatru umownego, nie może być jednoznaczne, skończone. Wszyscy mają świadomość tego, że Eulalia jest lalą, po czym traktują ją jak kobietę. Filmik natomiast stanowi doskonałe powtórzenie tego, co opisuje Boyé: artysta uczłowiecza manekina, a nie człowiek staje się manekinem, gra go. Zasada jest podobna do zasady funkcjonowania rysunku wielostabilnego - Eulalia będąc i jednym, i drugim równocześnie, ani jednym, ani drugim do końca nie pozostaje.

Białoszewskiego w jakiś sposób pociągały manekiny, były one również fascynującym tworzywem dla Buraczewskiej. Zapytana, jak powstała Eulalia, odpowiada: „Chciałam zrobić nie manekina, chciałam zrobić prawdziwego człowieka. Tak żeby nie był to manekin ani nic sztucznego" ${ }^{84}$. Tę ideę artystycznego stworzenia

${ }^{80}$ Fragment pracy magisterskiej, którą Białoszewski dedykował Agnieszce Kostrzębskiej (zob. A. S o b o l e w s k a, Maksymalnie udana egzystencja. Szkice o życiu i twórczości Mirona Białoszewskiego. Warszawa 1997, s. 39).

${ }^{81}$ B i a ło s z e w s k i w Mówieniu o pisaniu (s. 9) notuje, iż wzruszenia w sztuce tym różnią się od „tradycyjnych”, że „czas ich trwania jest krótszy, szybciej się zmieniają, ledwie się pojawiają, już następują inne".

${ }^{82}$ B i ałos zewski, S te fański,op.cit., s. 18.

${ }^{83}$ E. B o y é, Théâtre Art et Action. Scena paryska, która wystawiła „, Wesele”. „Wiadomości Literackie" 1925, nr 25, z 20 VI. Zagadką pozostaje, czy Białoszewski pamiętał ten artykuł, konstruując postać Ursyna z pseudocytatów z dzieła Wyspiańskiego.

${ }^{84}$ Fragment pochodzi z kasety, która znajduje się w moim archiwum. Buraczewska namówio- 
Eulalii przedstawił Białoszewski w narracji ${ }^{85}$. Eulalia wiąże filmikowanie z tradycją teatru lalek, jest również łącznikiem między filmikowaniem a teatrem Białoszewskiego. Analizę konwencji i stylu gry aktorów z Tarczyńskiej przeprowadził Jacek Kopciński, pokazując aktora teatru Białoszewskiego jako aktora ulalkowionego, który czerpie z tradycji futurystów, dadaistów i kubistów, by z tej perspektywy spoglądając na lalkę - w „metaforyczny sposób ukazać na scenie syntezę ludzkiego życia" ${ }^{86}$. Wychodzi na to, że przetworzonej tradycji Gordona Craiga dopatrzył się w teatrze Białoszewskiego również Tadeusz Sobolewski. Co więcej, w tej przetworzonej tradycji szukał inspiracji dla swoich działań filmowych. Mówił:

Ja po prostu w tej grze naśladowałem Mirona. On [...] pokazał nam kiedyś fragment kronik filmowych ze swojego teatru. Oni grali tam bardzo hieratycznie. Byli takimi manekinami, jak z Gordona Craiga ${ }^{87}$.

Ściśle ze stylem gry powiązany jest problem rytmu, tak istotny dla Białoszewskiego w jego rozważaniach o filmie. Sobolewski stwierdza: „Rytm był ważny. Rytm był najważniejszy”. A za chwilę dodaje: „Rytm, pamiętam rytm. A nie pamiętam, skąd on pochodził" ${ }^{88}$. Rytm nie pochodził z zewnątrz, nie używano bowiem muzyki w trakcie nakręcania scenek. Buraczewska wspominała, że Białoszewski bardzo często przynosił do nich płyty z muzyką, jednak wyłączał ją, kiedy rozpoczynano grę ${ }^{89}$. Jak wynika z relacji Buraczewskiej - Białoszewski mówił, iż aktorzy filmików powinni rytm odnaleźć w sobie. Odtworzenie tego rytmu stanowi klucz do animowania lalki-kobiety, aktora-manekina.

Sobolewski wskazuje na jeszcze jeden wymiar marionetkowości, związany bardziej ze sposobem funkcjonowania niż z konwencją czy stylem. Mówi, że w czasie filmikowania „było się użytym”. „Byłem aktorem obsadzanym w roli, ubieranym, rozbieranym. Niczego się nie bałem". A w trakcie oglądania filmików wspólnie z Anną Żurowską wspomina:

na przeze mnie, nagrała swoje wypowiedzi, przemyślenia dotyczące filmikowania, jej postrzegania sztuki ogólnie, ludzi, których spotkała.

${ }^{85}$ Warto nadmienić, że oprócz Eulalii stworzyła Buraczewska jeszcze dwie lale. Jedna z nich to ubrany w kapelusz i suknię krawiecki manekin, druga powstała ze starych malarskich sztalug, które w plastyczny sposób zostały przeobrażone w kobietę. Te manekiny grały razem z Buraczewską w scence reżyserowanej przez Białoszewskiego. Nie weszła ona do Snów pięciu osób, choć zapewne mogła, gdyby ktoś włączył kamerę. Białoszewski i Buraczewska zrealizowali ją, czekając na przyjście przyjaciół umówionych na filmikowanie.

${ }_{86} \mathrm{~J}$. K o p c iń s k i, Aktor ,, ulalkowiony” w teatrze Mirona Białoszewskiego, czyli, ,metafora $w$ działaniu”. „Dialog” 2006, nr 3. Ważnego zestawiania dokonał na gruncie semiotyki pomiędzy teatrem żywego aktora a teatrem lalek P. B o g a t y r i e w (O wzajemnych zwiazkach dwóch systemów. W: Semiotyka kultury ludowej. Wstęp, wybór i oprac. M. R. M a y e n o w a. Wyd. 2, poszerz. Warszawa 1979).

${ }^{87}$ Zacytowany fragment pochodzi z nagrania P. M o r a w sk i e g o, przygotowującego materiał do dokumentu $W$ pobliżu Mirona podczas spotkania z T. Sobolewskim, A. Sobolewską i A. Żurowską w Studiu Filmowym „Kalejdoskop” przy ul. Chełmskiej w Warszawie. Rozmowy, zapisane na taśmie VHS, są w posiadaniu reżysera.

88 Ibidem.

89 Raz tylko w czasie nagrywania scenki, w której Białoszewski przebrany za szamana tańczył, Buraczewska miała za zadanie wybijać rytm, uderzając dłońmi o taboret. Znamienne wszakże, że mimo iż scenkę powtarzano co najmniej czterokrotnie, wybijany rytm Białoszewski wykorzystał jedynie za pierwszym razem. 
Sobolewski: Lalki nie ma? Tam była lalka, ta najważniejsza postać.

Żurowska: To chyba Kicia Kocia grała tę lalę.

Sobolewski: Nie, to była lala Eulalia. Ta z tego opowiadania Eulalia, kiedy wszystkie jesteście zazdrosne o jej grę. Dlatego że on tak naprawdę potrzebował manekinów. Myśmy też byli manekinami, ale niedoskonałymi. Nie byliśmy dość posłuszni ${ }^{90}$.

Nie byli aktorami w wymiarze takim, jak widział to Konstantin S. Stanisławski. Działali na zasadzie przekaźników. Ich zadanie polegało na relacjonowaniu, przytaczaniu sytuacji, nastrojów, czyli na tym, na czym polegało zadanie aktorskie opisane w sztuce przedstawiania. Mieli odgrywać postacie, nie - być postaciami. Dlatego nie rażą sztucznością sceny, gdy aktorzy wychodzą z roli, śmiejąc się w momencie niespodziewanym dla założeń filmiku, spodziewanym natomiast dla sytuacji życiowej, sytuacji z poziomu ich przebywania na Żoliborzu. Przedstawiając postacie, pozostawali sobą i owo pozostanie widoczne jest w wypowiedzi artystycznej.

Eulalia - i kobieta, i lalka jednocześnie. Czyli aktorstwo nie mimetyczne, ale umowne, daje możliwość wieloznacznego i zarazem świadomego komponowania skojarzeń, aluzji, świadomego opowiadania o rzeczywistości. Sztuka, by uciec od kiczu ${ }^{91}$, powinna wchłaniać rzeczywistość jak ,wszystkożerne" ${ }^{92}$ bóstwo, by potem komponować dramat zgodnie z własnymi prawami i według własnych kryteriów.

Kwestia unaocznienia, uobecnienia rozumiana za Longinem, Cyceronem i Kwintylianem - jako wywołanie w słuchaczu żywych emocji - jest bezwzględnie bliska pojmowaniu literatury przez Białoszewskiego, nie wyłączając tej, może mając na względzie przede wszystkim tę twórczość, która dotyka problemów sztuki, o sztuce opowiada. Literatura, by być sztuką, musi tak konstruować swoje znaki, by jej pełne rozumienie dokonywało się nie tylko intelektualnie, ale również emocjonalnie, wzruszeniowo; zdaje się więc, że tym większy ciężar spoczywa na utworach podejmujących problem sztuki. Wzruszenie musi oddziaływać na czytelnika poprzez składniki artystycznego ukształtowania wypowiedzi, jak i w warstwie świata przedstawionego. Stąd tak istotna kwestia emocji w Eulalii, ich fluktuacja zmienności. Wywołanie w słuchaczu emocji to, z jednej strony, element konieczny ekfrazy, z drugiej - nadrzędny w pojmowaniu sztuki przez Białoszewskiego. Przeżycie jest więc całkowicie przynależne trzeciej warstwie, nazwanej przez Balcerzana ,ikonologiczną" ${ }^{93}$, przez Elsnera ,powierzchnią narracji interpretacyjnej" (E 75).

Jest w ostatnich akapitach Eulalii coś, co zastanawia. Bynajmniej nie idzie mi tylko o zachowanie Ursyna. Uwagę czytelnika przykuwa bowiem również zestaw środków, jakimi posłużył się mówca opisując Ursyna, który rusza na ratunek Eulalii:

Wtem pan Ursyn spostrzegł osaczenie Eulalii. Rzucił się sztywno na ratunek. Błysk okularów. Wziął Eulalię w ramiona i uniósł do ciemnego pokoju.

I dalej:

Pan Ursyn zniknął z Eulalią w głębi salonu. Coś tam chrzęściło. [B 298]

Dlaczego pan Ursyn na ratunek rzuca się „sztywno”, a nie „szybko”? Dlacze-

\footnotetext{
${ }^{90}$ Fragment z nagrań M o r a w s k i e g o. Zob. tu przypis 87.

${ }_{91}$ Zob. B i ało s z e w s ki, Coś mnie ciagnie.

${ }_{92}$ M. B i a ł o s z e w s k i, Baśka. W: Przepowiadanie sobie, s. 277.

${ }^{93}$ B a lc e r z a n, op. cit., s. 148.
} 
go to okulary mu błyszczą, a nie oczy? Dlaczego „unosi” ją do pokoju, a nie „wynosi”? I co oznacza ostatnie zdanie: co „chrzęściło”? Jak mi się wydaje, w Eulalii chrzęści i pobrzmiewa Wesele Wyspiańskiego.

Pan Ursyn jest niczym błędny rycerz z dramatu, jaki umyślił stworzyć Poeta:

$$
\begin{aligned}
& \text { Taki mi się snuje dramat } \\
& \text { groźny, szumny, posuwisty } \\
& \text { jak polonez; gdzieś z kazamat } \\
& \text { jęk i zgrzyt, i wichrów świsty. - } \\
& \text { Marzę przy tym wichrów graniu - } \\
& \text { o jakimś wielkim kochaniu. } \\
& \text { Bohater w zbrojej, skalisty, } \\
& \text { ktoś, jakoby złom granitu, } \\
& \text { rycerz z czoła, ktoś ze szczytu } \\
& \text { w grze uczucia, chłop qui amant, } \\
& \text { przy tym historia wesoła, } \\
& \text { a ogromnie przez to smutna. }
\end{aligned}
$$

Który dalej opowiada Gospodarzowi:
A wszystko bajka wierutna.
Wyraźnie się w oczy wciska, zbroją świeci, zbroją łyska postać dawna, coraz bliska, dawny rycerz w pełnej zbroi, co niczego się nie lęka ${ }^{94}$.

Gra kryptocytatami z Wesela tworzy naddatek - „bajkowy” wymiar, który pozwala tłumaczyć zachowanie Ursyna. Pan Ursyn sztywno rzuca się na ratunek, bo jest niczym okuty w zbroję rycerz, ten błysk okularów stanowi odbicie błysku metalu, a Eulalia nie może być wynoszona, bo Ursyn unosi ją na wyimaginowanym koniu.

Projektowany utwór Poety to dramat o wielkiej miłości, smutny i wesoły zarazem - niczym nieszczęśliwe i komiczne zauroczenie Ursyna lalą. Dramat „szumny i posuwisty” jak polonez, ,z jękiem, zgrzytem, wichrów świstem” dochodzącymi z lochów. Nie tylko dramat, czyli przestrzeń sztuki, „zgrzyta” i „chrzęści” u Wyspiańskiego. Bo przecież:

$$
\begin{aligned}
& \text { tak by się nam serce śmiało } \\
& \text { do ogromnych, wielkich rzeczy, } \\
& \text { a tu pospolitość skrzeczy, } \\
& \text { a tu pospolitość tłoczy, } \\
& \text { włazi w usta, uszy, oczy }{ }^{95} \text {. }
\end{aligned}
$$

Bohater z nienapisanego dzieła Poety staje jednak rażony własną niemocą, czerpie „męty ze studni”, choć „pragnie zdroju”. „Wszystko to bajka wierutna”mówi Poeta, a jego dzieło nigdy nie powstaje. Pan Ursyn, ratując Eulalię, pozwala wygrać się dramatowi-komedii do końca. Nie jest to dramat na miarę wieszcza, bo taki paraliżuje działanie, to dramat na miarę Ursyna, na miarę filmikowania.

W Eulalii sztuka nie ma ostrego podziału na wysoką i niską, zadanie każdej BN I 218.

${ }^{94}$ S. Wy s p i án s k i, Wesele. Oprac. J. N o w a k o w s k i. Wyd. 5. Wrocław 1994, s. 60-61.

${ }^{95}$ Ibidem, s. 62-63. 
wypowiedzi artystycznej wiąże się z funkcjonowaniem blisko życia, a funkcjonuje tak, jeżeli opowiada o przeżyciu albo owo przeżycie podpatruje. Sztuka jest „Rodzajem bóstwa, które ma szanse na dłuższe trwanie kosztem każdym, co podleci”, jest „wszystkożerna” ${ }^{96}$. Skrzecząca i chrzęszcząca pospolitość, ale nasycona emocjami, staje się źródłem sztuki.

W Weselu niebywale istotny jest motyw (pobrzmiewający i w zacytowanych fragmentach) niewspółmierności słów do czynów, przegadania czynów prowadzącego do zaniechania, słabości, niemocy. Ursyn nie mówi, ale działa. Tyle że nie mamy pewności, jak dalece to działanie udaje się przełożyć na rzeczywistość, a jak bardzo jest to tylko teatralny (filmikowy) gest, jak dalece jest to uchwycenie rzeczywistości, jej diagnoza, a w jakim stopniu ironiczna gra kliszą romantyczną z czytelnikiem (słuchaczem). Białoszewski podobnie jak Wyspiański chce dotykać granic życia i teatru (filmu), wskazywać na płynność granic, bawić się (i doświadczać) tego kuszącego zacierania granic między porządkami. Ten brak pewności przestrzeni, w jakiej się poruszamy, doskonale komentuje końcowy „chrzęst”. Ursyn w swym działaniu jest niezwykle rycerski i chcemy wierzyć (być może, razem z Białoszewskim), że udało się mu dokonać czynu, który nie jest przerostem formy nad treścią, ale jednocześnie Ursyn bardzo przypomina Don Kichota czy postać z Chaplinowskiej burleski.

Co jeszcze łączy Eulalię z Weselem? Najprościej mówiąc: geneza. Obydwa utwory są efektem przenikania się życia i sztuki. W obydwu łatwo można wskazać postacie, które miały swój pierwowzór w konkretnych osobach z otoczenia twórców. Obydwa teksty to wynik pracy wyobraźni wyczulonej na teatralno-filmowy potencjał rzeczywistości, przekształcającej w kod sztuki konkretnych ludzi zobaczonych w konkretnych sytuacjach. I jeden, i drugi tekst przenosi prywatną imprezę w przestrzeń sztuki. Poza tym znamienna jest dla nich jawna ,nieobecność” autorów dzieł. Wyspiański był przecież gościem na weselu Lucjana Rydla, filmikowanie bez Białoszewskiego z reguły nie odbywało się. $Z$ drugiej strony, wielu interpretatorów dopatruje się w postaci Chochoła pewnej imaginacji samego Wyspiańskiego ${ }^{97}$, natomiast postacie z Eulalii mają wszczepione cechy, które należałoby przypisać Białoszewskiemu ${ }^{98}$.

Znacząca jest również kwestia rytmu Wesela, która była niesamowicie ważna dla Białoszewskiego, poświęcił jej wiele uwagi w eseju O tym Mickiewiczu, jak go mówię $^{99}$. Rytm wypływa też, gdy Białoszewski mówi o kinie niemym. Tak więc Eulalia byłaby punktem, w którym te literacko-filmowe rozważania dotyczące rytmu się spotykają.

${ }^{96}$ B i ało s ze w s ki, Baśka, s. 277.

${ }_{97}$ Zob. Z. K ę p iń s k i, Stanisław Wyspiański. Warszawa 1984.

${ }_{98} \mathrm{~Np}$. sztuczne zęby Ursyna, które przywołują cykl zatytułowany właśnie Sztuczne zęby, czy Mariana niechęć - pomimo nacisków przyjaciół - do grania, odzwierciedlająca rozmowę M. B i ało s zew ski e g o z Tadziem przytoczoną w Majowym przejściu (w: Rozkurz. Warszawa 1998, s. 47). A. Sobolewska twierdzi, że Białoszewski tworzył swoje postacie, łącząc jakiś pierwowzór, osobę, która należała do jego otoczenia, z sobą samym (zob. Nie mogę kołysać się razem ze wszystkimi. Z A. i T. Sobolewskimi rozmawia J. M a j c h e r e k. „Teatr” 1993, nr 5).

${ }_{99}$ Kwestię złożoności problemu rytmu w dramacie Wyspiańskiego podjęła ostatnio M. P r u ss a k w książce Wyspiański w labiryncie teatru (Warszawa 2005), czyniąc pewne podsumowanie dotychczasowych prób ujęcia zagadnienia. O problemie rytmu B i a ł o s z e w s k i pisze w tekstach O tym Mickiewiczu, jak go mówię i Coś mnie ciagnie. 
Interpretatorzy Wesela siłą rzeczy wiele uwagi poświęcają kwestii osób dramatu. W kontekście Eulalii interesujące będą dla mnie słowa samego poety, które przypomina Pigoń. Wyspiański w Studium o Hamlecie mówi o „prawdzie światów innych", która - zdaniem Tadeusza Nyczka - jest doświadczana w osobistym przeżyciu śmierci bliskiej osoby i wiąże się z wrażeniem przeżywania bliskości jej ducha w bezpośrednim otoczeniu ${ }^{100}$. Podobną wartość, znaczenie ma pojawiający się w Eulalii duch psa wspomniany przez Ursyna, jest to „osoba dramatu” skonstruowana adekwatnie do założeń opowieści o filmikowaniu. Duch psa wprowadza inny punkt widzenia w poszukiwaniu relacji między życiem a sztuką.

To nie przypadek, że odnajdujemy w opowiadaniu, gdzie główną bohaterką jest rzeźba-kobieta, kryptocytaty nawiązujące do Wesela, dramatu, którego inscenizacja z 1923 roku zainspirowała Stefańskiego do stworzenia Teatru na Tarczyńskiej. Inscenizacja, która oparta była na scaleniu w jeden znak sceniczny aktora i marionety. Zasadniczy pomysł Marie Antoinette Allévy-Viola i Luise Lara zainspirowany był przemianą weselnej chaty w szopkę, na proscenium umieszczono napis: „A słowo ciałem się stało i mieszkało między nami”, co - jak sugeruje Rafał Węgrzyniak - stanowiło realizację wcześniejszego postulatu Edwarda Łady-Cybulskiego (tłumacza Wesela na język francuski), by napis taki znajdował się na belce w izbie weselnej w inscenizacji krakowskiej. Spektakl przedstawiał weselników jako kukły z szopki. W akcie I aktorzy ubrani byli w papierowe kostiumy, w akcie II pojawiające się osoby dramatu odtwarzane są przez aktorów, natomiast weselników zastępują papierowe marionety.

W akcie III przez scenę przesuwają się wyłącznie owe marionety - „kukły z szopki” (Gospodarz, Gospodyni, Pan Młody, Panna Młoda, Dziennikarz, Czepiec, Rachel). Jedyną postacią graną przez aktora był w epilogu Jasiek. Kostiumy aktorów, jak i marionety stworzono stylizowane, niemal umowne, na ogół biało-czarne. Marionetę Chochoła wykonano ze słomy. Przez szeroko rozstawione źdźbła widać było w jej wnętrzu kwiat róży, a nad nim trupią czaszkę, co oddawało dwuznaczność symbolu zarazem życia i śmierci ${ }^{101}$.

Ta ciągła transformacja i oscylacja bohaterów dramatu między marionetką a osobą w eksperymencie zorganizowanym przez Le Théâtre Universitaire Art et Action buduje napięcie podobne jak w przypadku Eulalii. Co więcej, inscenizacja przygotowana według egzegezy Łady-Cybulskiego zdaje się wyjaskrawiać w tym silnie narodowym dramacie akcenty poruszające kwestie sztuki oraz styku teatru i rzeczywistości, o której teatr opowiada.

I niech będzie to już ostatnia rzecz, chociaż, jak sądzę, tych wspólnych cech jest znacznie więcej. Sen jako stały element Wesela - począwszy od róży symbolicznie śpiącej w Chochole, przez poszczególne osoby zasypiające, usypiane albo opanowywane przez senność, aż po osoby dramatu będące gośćmi z osobistych koszmarów i obaw - wydaje się płaszczyzną, na której sportretować można najdogodniej relację między rzeczywistością a sztuką. Dla Białoszewskiego oniryzm, sen jest równie ważny w całej jego twórczości, jak i w wypowiedziach o kinie

${ }^{100}$ T. N y c z e k, „Pióra orle, pawie, gęsie”. Przedmowa w: S. Wy s p i a ń s k i, Wesele. Kraków 1996, s. 24. Lekcja literatury z Tadeuszem Nyczkiem.

${ }^{101}$ Lalki. Hasło w: R. W ę g r z y n i k, Encyklopedia „,Wesela” Stanisława Wyspiańskiego. Kraków 2001. 
niemym. Senna logika stanowi kanwę filmikowania jako takiego i okazuje się dominująca także w narracji Eulalii.

Mowa posługująca się cytatem lub kryptocytatem nie używa swoich znaków. Jednak anektując znaki Innego, zarazem otwiera się na dyskurs Innego, na dialog z Innym. Równocześnie - trzymając się terminologii Lacana - ponownie, jak w przypadku tekstu z dziennika Białoszewskiego, można mówić o stadium lustra. Tyle że autor Rozkurzu nie staje się tu obrazem samego siebie, jest raczej obiektem, na który spogląda obraz. Podobnie jak Filostrat Młodszy ustawia się względem Filostrata Starszego, tak Białoszewskiego w konstrukcji Lacanowsko-Elsnerowskiej należy ustawić względem Wyspiańskiego.

Pojawiający się w Eulalii dialog z Weselem pozwala interpretować narrację jako wielopoziomowy dyskurs o relacjach między sztukami, o przenikaniu się sztuk oraz o relacji między życiem a sztuką i o przenikaniu się życia i sztuki. Sądzę, że kwestia ekfrazy, ekfrastyczności czy bardzo asekuracyjnie to nazywając: zjawiska ekfrastycznego, świetnie wpisuje się w tę problematykę, co więcej, pomaga wydobyć dodatkowe aspekty.

\author{
A bstract \\ IZABELA TOMCZYK \\ (Cardinal Stefan Wyszyński University in Warsaw) \\ DESCRIBING AMATEUR SHORT FILM MAKING. \\ "EULALIA" AS AN EKPHRASIS \\ OF THE SHORT MOVIE "NAPAD NA STACJI” (“ASSAULT AT THE STATION”)
}

The text attempts at an interpretation of Miron Białoszewski's prose Eulalia. The title heroine is a doll, a mannequin, which Białoszewski's friend Adriana Buraczewska made of paper mass and colourfull pieces of cloth. Eulalia appears in Białoszewski's few movies, i.e. short silent films produced in Ada and Roman Klewin's flat in Warsaw district of Żoliborz. The story in question is the only one in Białoszewski's creativity, which the poet exclusively devoted to filming.

Starting from the meaning of the heroine ("Eulalia" is the one who is distinguished as having the values of a speaker), the author tries to prove that the piece is an ekphrasis of a silent movie. Exploring the rich ekphrasis-researching tools, the author choose the approach proposed by Jan Elsner. It allows for an examination of the relationship between the word and the picture as well as adds the problems of movie and look into its considerations. 